\title{
DISCIPLINA CIENTÍFICA COLONIAL Y COPRODUCCIÓN ETNOGRÁFICA. LAS EXPEDICIONES DE MARTÍN GUSINDE ENTRE LOS YÁMANA DE TIERRA DEL FUEGO ${ }^{1}$
}

\author{
JORGE PAVEZ OJEDA*
}

\begin{abstract}
RESUMEN
Se proponen algunas herramientas conceptuales y ejes de análisis para el estudio de la historia de la antropología, y se aplican al trabajo de Martín Gusinde y sus colaboradores en Tierra del Fuego. El estudio de caso se centra en tres dimensiones de la representación etnográfica llevada a cabo por Gusinde: 1) la importancia teórica del estudio del "monoteísmo primitivo" en las discusiones europeas sobre las "razas más primitivas", 2) la coproducción dialógica de la representación etnográfica y las formas del intercambio etnográfico en situación colonial, y 3) la importancia teórica y empírica de la infancia en las concepciones primitivistas degeneracionistas.
\end{abstract}

PALABRAS CLAVE: etnografía, representación, Yámana, colonialismo, Etnoteología.

\section{COLONIAL REPRESENTATION, SCIENTIFIC DISCIPLINE AND ETHNOGRAPHIC CO- PRODUCTION. MARTIN GUSINDE SDV. AND THE YÁMANA OF TIERRA DEL FUEGO}

\begin{abstract}
Some concepts and analytical axes are proposed for the study of the history of anthropology, and applied to the field work of Martin Gusinde and collaborators in Tierra del Fuego. The case study is centered in three dimensions of the ethnographic representation developed by Gusinde: 1) the theoretical importance of the study of "primitive monotheism" in European discussions about "primitive races", 2) the dialogical coproduction of the ethnographic representation and the forms of ethnographic exchange in colonial situation and 3) the theoretical and empirical importance of childhood in the primitivist degenerationist conceptions.
\end{abstract}

KEY WORDS: ethnography, representation, Yámana, colonialism, ethnotheology.

1 Una primera versión de este artículo fue presentada en las Jornadas de estudio "Formas del colonialismo nacional" realizadas el 14-15 de diciembre 2011 en el Museo Regional de Magallanes, Punta Arenas. El artículo y las jornadas se enmarcan en el proyecto de intercambio ECOS-CONICYT C09H01 Formas del colonialismo republicano (2010-2012). Agradezco a Joaquín Bascopé la invitación a estas jornadas.

Instituto de Investigaciones Arqueológicas y Museo, Universidad Católica del Norte. Calle Le Paige 380, San Pedro de Atacama, Chile. Email: jpavez@ucn.cl. 
Ha llegado la etnología a tal grado de perfección, que asombra por sus progresos

Aureliano Oyarzún (1935)

Por más que se lo compadezca, el peculiar pueblito de los yámana ha desaparecido para siempre Martín Gusinde (1937)

Según estos epígrafes, dos años después de haber alcanzado la etnología una asombrosa perfección, el pueblo de los yaghanes ahora llamados yámana por el sacerdote etnólogo Martín Gusinde, habría desaparecido para siempre... Esta conjunción del auge de una ciencia y la muerte de un pueblo obliga a preguntarse cómo se relacionan los agentes y los aparatos que operan en está "desaparición". Para acercarse a una respuesta, es importante recordar que la constitución de colectividades políticas (pueblos) implica la instauración de un principio de representación, el que involucra un principio de soberanía jurídica y un mecanismo disciplinario de registro y control. En conjunto, soberanía y disciplina instauran la representación política como principio de sujeción a la ley y como representación descriptiva y contable, es decir, la doble inscripción -jurídica y productiva- de los cuerpos. Por una parte, la voz y la autoridad de quien habla por el cuerpo colectivo, por una persona jurídica o natural; por otra, la representación como imagen de clase, lo que se ve de la etnia, raza, pueblo o categoría social, el retrato que hace visible el cuerpo de la representación, su lugar y su posibilidad como pura representación. ${ }^{2}$ En las agencias e instituciones político-etnográficas surge entonces la cuestión de los representantes, autores o autoridades, trabajadores o dueños de la representación, como sujetos que pueden articular los planos de la economía y la soberanía, la agencia y la disciplina, la administración e inscripción estatal y el sistema intercambiario y productivo. La economía de la representación etnográfica de las poblaciones conquistadas presenta un conjunto de problemas relativos a la acumulación y distribución de conocimientos, riquezas y poder, los que se articulan con el de las formas de producción y propiedad de estos capitales de saber-poder. Acumulación de informes e informaciones, acumulación de informantes y textos,

2 Gayatri Ch. Spivak, Historia, en R. Rodríguez F. (ed.), La (re) vuelta de los Estudios Subalternos (San Pedro de Atacama, 2011), pp. 137-154. acumulación de objetos y cuerpos para el estudio; a la vez que producción de textos, sujetos y corpus, desde el estudio, en el terreno, el gabinete o la oficina. La producción de conocimiento sobre los colonizados, por ser una producción para la representación va a ser atravesada por intereses y aparatos de captura, que intentarán insertarla en ciertos regímenes más generales de acumulación y de reproducción de clases económicas y sociales, clases que los agentes etnológicos son llamados a representar (hablar) por encima (o por abajo) de los mismos representados. En el proceso de representación colonial que implica la producción del indígena, de lo indígena como lo que hay que administrar, civilizar y nacionalizar, emergen las agencias y autoridades de la representación. En este proceso histórico se puede ver con Foucault ${ }^{3}$ un movimiento desde la soberanía política y la sujeción jurídica, hacia la descripción de los cuerpos y la objetivación administrativa de la individualidad disciplinar; o con el Marx del 18 de Brumario, un movimiento contrario que va de la representación en sí, como descripción literal, histórica y estadística de las clases y los sujetos colectivos, a la representación para sí, como toma de conciencia y auto-representación de la clase en diagramas de intereses antagónicos, un paso desde el retrato de las clases y sus intereses (darstellen) al "hablar por" la clase y sus deseos (vertreten). ${ }^{4}$ Como en el caso de los campesinos franceses y su apoyo a Napoleón en la contra-revolución del 48, "no pueden representarse a sí mismos, tienen que ser representados" por quién hace de padre de la nación (Marx), la clase que no puede representarse a sí misma, no estaría aún madura como clase. No habría producido un "suplemento de origen" como

3 Para Foucault, el derecho de la soberanía (ley) y la mecánica de la disciplina (normalización, ciencias humanas) serían profundamente incompatibles, sustituyendo la segunda al primero. Cf. Michel Foucault, Defender la sociedad. Curso en el Collège de France 1975-1976 (Buenos Aires, 2000), pp. 43-45. Nos interesa mostrar que, en algunos casos, el desarrollo de las disciplinas científicas en territorios indígenas está estrechamente ligado a formas "tradicionales" o "clásicas" del poder soberano y al ámbito de negociación jurídica, y que el desarrollo de las disciplinas científicas (para la administración biopolítica) se afirma sobre formas soberanas del poder, y que al mismo tiempo, la soberanía (republicana o indígena) requerirá de las disciplinas para reproducirse en situación colonial. Sobre la soberanía en la representación, ver Foucault, Les mots et les choses (Paris, 1965).

4 Spivak, 2011 op cit, pp. 135-139. 
"movimiento de substitución" para sí: la posibilidad de producir con retraso aquello a lo cual dice agregarse, es decir, el suplemento sustitutivo que está en el origen de la clase en sí. ${ }^{5}$

La producción antropológica que acompañó la conquista de territorios independientes a finales del siglo XIX, cumplió precisamente la función de representar descriptivamente las poblaciones colonizadas. En los casos en que predominó una forma republicana del colonialismo, es decir, un proyecto de integración de estas poblaciones a la comunidad y el cuerpo político nacional, esta representación también adquirió un carácter político, el de una mediación que requirió de sujetos llamados a "hablar por" los indígenas. La práctica, las instituciones y los agentes de la antropología se instalaron en ese lugar de producción de representaciones. La noción de "gabinete etnográfico" nos permite comprender las formas en que se organiza la producción de representaciones antropológicas atendiendo a las prácticas etnográficas, los agenciamientos institucionales y políticos, la inscripción en corrientes paradigmáticas y formaciones discursivas, y la inserción en redes de circulación, intercambio y difusión de la información, redes que adquieren en estos gabinetes un estatus científico. Se puede así combinar el estudio de las formaciones disciplinarias en base a una arqueología del discurso en el archivo de los enunciados ${ }^{6}$ con una aproximación sociológica de la configuración histórico-institucional de los saberes y sus agentes disciplinarios $^{7}$ y una lectura antropológica de la producción del conocimiento etnográfico. ${ }^{8}$ Para esto, hay que considerar dos niveles de producción

5 Jacques Derrida, La voix et le phénomène (Paris, 1967), p. 104.

6 Michel Foucault, L'archéologie du savoir (Paris, 1969) y Histoire de la sexualité I. La volonté de savoir (Paris, 1976); Edward Said, Orientalism (London, 2003 [1978]); Valentin Mudimbe, The invention of Africa (Bloomington \& London, 1988).

7 Georges Stocking, Race, Culture, and Evolution (Chicago \& London, 1968); The Ethnographer's Magic and others essays (Madison, 1992) y Delimiting anthropology (Madison, 2001); Fabiani, Faire école en sciences sociales: un point de vue sociologique, Cahiers du Centre de recherches historiques 36 : 191-207 (2005).

8 James Clifford, Dilemas de la cultura (Buenos Aires, 1995); Mariza Peirano, 'In this context'. As várias histórias da antropologia, en F. Arêas Peixoto, H. Pontes, L. Moritz Schwarcz (orgs.), Antropologias, Histórias, Experiências (Belo Horizonte, 2004), pp. 99-121. y significación de los textos etnológicos: el de la "biblioteca" o "archivo" en sentido amplio, como el lugar de acumulación, clasificación y lectura de los textos, donde se despliega una intertextualidad significante y productora del sentido, de las disciplinas y de las áreas culturales; ${ }^{9}$ y el del "gabinete etnográfico". A pesar de su productividad e utilidad para abordar los corpus que conforman culturas (para abordar, por ejemplo, lo que sería la constitución del "araucanismo" o del "andinismo"), las aproximaciones foucaultianas del archivo de los enunciados limitan la lectura de los textos etnológicos como producciones dialógicas o textualidades polifónicas, surgidas de la coproducción etnográfica del conocimiento antropológico, coproducción en la que participan en diversos grados los agentes indígenas, ya sea en el ámbito de la generación de condiciones políticas para hacer posible la etnografía, ya sea en la misma "operación etnográfica", como autores y escritores, coproductores del texto etnológico. ${ }^{10}$ En el segundo

9 Es lo que muestran, Valentin Mudimbe, op. cit. 1988, en su análisis de la "biblioteca colonial" africanista (de administradores coloniales, misioneros y etnólogos) como responsable de una "invención de África" instituida y objetivada por discursos de la similitud (de lo Mismo) en su oposición a la alteridad radical (el afuera de la historia occidental) que es también un discurso de lo Mismo; y el trabajo clásico de Edward Said, op. cit. 2003, sobre el archivo orientalista como un conjunto de textos y enunciados que conforman un principio de organización del saber, en base a autores que adoptan una posición estratégica en esta red de textos ("strategic location"), la que por su parte conforma estratos de enunciados de una cierta masa y densidad ("strategic formation") (Said, ibid., p. 20).

10 Judith Berman, The Culture as it Appears to the indian Himself: Boas, Hunt, and the Method of Ethnography, en G. W. Stocking Jr. (ed.), Volksgeist as Method and Ethic. Essays on Boasian Ethnography and the German Anthropological Tradition (Madison, 1996), pp. 215-256; Jorge Pavez, Mapuche ñi nütram chilkatun/ escribir la historia mapuche, Revista de Historia Indígena 7: 7-53 (2003). Como ha señalado L. Dartigues, estas lecturas foucaultianas no dejan mucho espacio a la comprensión dialógica de la co-producción de conocimientos entre investigadores coloniales y agentes indígenas, y las formas de participación indígena en esta producción. El mismo Said muestra una lectura muy restringida de la teoría del dialogismo bajtiniano, acusándola de "discurso domesticado" por la colonización (cf. Said, Representar al colonizado: los interlocutores de la antropología. En B. González Stephan (ed.), Cultura y tercer mundo. 1. Cambios en el saber académico, (Caracas, 1989); y Laurent Dartigues, La production conjointe de connaissances en sociologie historique : quelles approches? quelles sources? Le cas de la production orientaliste sur le Viêtnam 1860-1940, Genèses 43: 53-70 (2001/2002). 
nivel, menos estabilizado que la biblioteca/archivo, se encontrará el gabinete etnológico (o laboratorio etnográfico), que entendemos no como el escritorio del etnólogo metropolitano alejado de los territorios de colonización, sino precisamente el lugar periférico donde se constituye la agencia etnográfica, por la reunión siempre experimental de diferentes practicantes de una "operación etnográfica". Al igual que la "operación historiográfica" estudiada por Michel de Certeau, esta operación etnográfica es la condición de todo archivo o biblioteca de la alteridad, y es producida por una relación entre un lugar (un reclutamiento, un medio, un oficio, etc.), procedimientos de análisis (una disciplina) y la construcción de un texto (una literatura), combinando de esta manera un lugar social, prácticas 'científicas' y una escritura. ${ }^{11}$ Se trata así de la producción de la "autoridad" en la representación y por la representación, de la producción de las subjetividades y las sujeciones de los (co)autores de los textos y de las políticas indígenas o indigenistas.

Con estos instrumentos, intentaremos acercarnos al lugar de la antropología fueguina en la representación colonial, la producción de soberanía y la reproducción disciplinaria de la antropología, para las cuales el trabajo de Martín Gusinde parece un caso paradigmático. En el caso Gusinde, por debajo de su trabajo de documentación etnográfica y de su representación política de los pueblos australes, quizás como sustrato de estas dos dimensiones, subyacen tres aspectos que proponemos analizar aquí: 1) la misión teológica que orienta sus expediciones científicas, incorporando el caso de los yagán a las discusiones antropológicas europeas; 2) la importancia del intercambio y compensación de los indígenas para su participación en la producción antropológica de lo étnico; y 3) el lugar estratégico de la infancia y de la relación con los niños para la producción antropológica en sociedades colonizadas. Revisando estos aspectos en el caso específico de Gusinde, veremos que parecen repetirse ciertas pautas comunes en la lógica colonial de la producción científica.

11 Michel De Certeau, L'écriture de l'histoire (Paris, 1975) p. 64. Esta propuesta de de Certeau anuncia en cierta medida la perspectiva que desarrollará Bruno Latour para el estudio de la "literatura científica". Cf. Latour, La science en action (Paris, 1989), pp. 59-152.
Watauinewa "like Christian God": dialogismo etnográfico, secretos iniciáticos y división internacional del trabajo de traducción

Martín Gusinde S.V.D. es el único etnógrafo de Sudamérica que aparece en la primera Historia de la etnología, la de Robert Lowie, discípulo de Franz Boas y Wilhem Koppers, publicada en 1937. ${ }^{12}$ El nombre de Gusinde no aparece sólo, sino asociado al de su maestro Wilhem Schmidt, del Instituto y revista Anthropos de Viena, y su empeño por demostrar la existencia del monoteísmo en los llamados pueblos primitivos. El hallazgo de Gusinde de creencias monoteístas entre los yagán de Tierra del Fuego contribuye al grueso expediente que prepara Schmidt para una demostración que quiere demoler definitivamente la teoría de Edward B. Tylor sobre el animismo primitivo y la emergencia del monoteísmo a través de un largo proceso de evolución religioso-cultural. Así Tylor negaba que los pueblos mas "simples" puedan tener grandes divinidades, en la medida que homologa la evolución material de la cultura a la de sus valores espirituales. ${ }^{13}$ A principios del siglo XX, los etnógrafos esparcidos a lo largo y ancho del mundo colonizado han colectado muchas evidencias que cuestionan desde varios flancos el modelo evolucionista tyloriano. A la crítica de Andrew Lang, ${ }^{14}$ se suma la del padre Schmidt en los seis volúmenes de su Der ursprung der Gotesidee, publicados entre 1926 y 1936. En esta suma monoteísta, el hallazgo de Gusinde de "un ser supremo libre de caracteres mitológicos" entre los fueguinos adquiere un importante rendimiento. Sin embargo, en la muy

12 Robert Lowie, Historia de la etnología (México, 1971 [1937]), pp. 78-79. El hecho que Lowie haya sido alumno de Koppers, quién participó en la expedición a Tierra del Fuego de 1921-1922, puede explicar también la mención a Gusinde en la Historia de la etnología. Cf. R. Cárdenas, Prólogo en W. Koppers, Entre los fueguinos (Punta Arenas, 1997), p. 8.

13 Cf. la crítica de W. Schmidt a E. Tylor en Origine et évolution de la religion. La Théorie et les Faits (Paris, 1931).

14 A. Lang, Magic and Religion, 1901. La intervención de Lang se enmarca también en una fuerte corriente crítica del positivismo, donde los científicos como el mismo Lang se permiten incluso ver y defender la existencia de "fantasmas" o "espíritus" espiritistas. Cf. G. Stocking, Books unwritten, turning points unmarked: notes for an anti-history of anthropology, Delimiting anthropology: occasional essays and reflections (Madison, 2001), pp. 336-337. 
católica República de Chile, el monoteísmo de los fueguinos será también ampliamente comentado y difundido, en una suerte de rehabilitación de los "salvajes" que favorecía el intento del colonialismo chileno de darle credenciales morales y religiosas a los orígenes étnicos de la república. ${ }^{15}$ De esta manera, quién fue visto en Chile como un importante intelectual metropolitano que viajaba a la periferia del mundo a producir conocimiento antropológico, entra a la historia de la etnología como un simple informante etnográfico en una discusión teórica cuyos protagonistas son el inglés Tylor y el austríaco Schmidt quién, a contrapelo del teórico inglés, plantea que es el monoteísmo originario que degenera en el politeísmo de agricultores matrilineales y cazadores totémicos, lo que André Mary llama un "evolucionismo al revés". ${ }^{16}$ Sin duda que la acumulación de informes etnográficos y de una gran masa de datos "frescos" terminan por colapsar la teoría evolucionista lineal. Según Georges Stocking, la amplitud de estos informes es responsable del hecho que Tylor nunca haya podido

15 El "descubrimiento" de Gusinde será difundido y valorado por los indigenistas chilenos como: Aureliano Oyarzún, quien se hace divulgador de la escuela histórico-cultural (La idea de Dios en Tierra del Fuego en A. Oyarzún, Estudios antropológicos y arqueológicos (Santiago, 1979), pp. 226-230); Carlos Keller, quién lo desarrolla en una colección de cuentos Dios en Tierra del Fuego (Zig Zag, 1947), y Alejandro Lipchutz, Los últimos fueguinos: transculturación y desculturación, extinción y exterminación, Perfil de Indoamérica de nuestro tiempo (La Habana, 1972 [1968]), pp. 199-228. El escritor kawésqar Juan Carlos Tonko expresó hace unos años su molestia por esta recuperación monoteísta de las creencias indígenas por Gusinde y los que le siguieron (incluyendo los operadores turísticos contemporáneos), denunciando el mito del supuesto dios Xolas o Cholas como lo describe Martin Gusinde. El objetivo de Gusinde, dice Tonko, era demostrar que todos los pueblos indígenas tenían un dios único y de ahí proviene el origen de este famoso dios Xolas. Cf. J.C. Tonko, Ajajema y Jeksolok, Informativo Indígena de Magallanes 1 (3):1 (2000).

16 A. Mary, "La preuve de Dieu par les pygmées", Cahiers d'études africaines 198/199/200: 881-905 (2010); Rodrigo Cárdenas y Alfredo Prieto, Entre los fueguinos: ¿una reacción antievolucionista de la escuela histórico-cultural?, Anales del Instituto de la Patagonia 27: 89-98 (1999); sobre la teoría del monoteísmo de Schmidt, ver H. Zimón, Wilhem Schmidt's Theory of Primitive Monotheism and Its Critique within the Vienna School of Ethnology, Anthropos 81 (1/3): 243-260; y para las reflexiones de M. Gusinde sobre el tema, ver Hombres primitivos en la Tierra del Fuego, (Sevilla, 1951), pp. 318-319, entre otros. publicar una revisión general de la teoría animista presentada en Primitive Culture (1871), a pesar de haber confiado en el trabajo de los misioneros y difusionistas boasianos para la resolución de las anomalías de su teoría evolucionista. ${ }^{17}$ Para Stocking, la mayoría de los proyectos tardíos inconclusos de los padres fundadores de la disciplina antropológica constituyen marcadores silenciosos de un punto de inflexión mayor, ${ }^{18}$ donde la inconclusión se debe precisamente a que la teoría ha sido atrapada en la tensión entre el cientificismo de lo universal y el relativismo de lo particular, tensión donde las relaciones humanas (la "empiria", el "trabajo de terreno") oponen resistencia a la formulación de leyes universales, generando así el "fracaso o frustración del impulso científico" como común denominador de los "libros inconclusos". ${ }^{19}$ De esta manera, los puntos de inflexión paradigmática significados en los proyectos inconclusos serían la prueba misma de la dificultad de una síntesis general de todos los informes específicos producidos por una disciplina particularista como la etnología. Es también a este punto que apuntaba el filósofo compatriota de Gusinde, Ludwig Wittgenstein cuando criticaba molesto al Frazer de La Rama Dorada (1911-1915), quién desde su gabinete londinense recibía e intentaba explicar los informes etnográficos de todas partes

17 Stocking, 2001, op. cit., pp. 336-337. El alegato de Gusinde en el informe de su último viaje a Tierra del Fuego es tajante respecto a la desgracia en que ha caído la antropología evolucionista y sus métodos "de salón": Sería también para mi mucho más cómodo y fácil, sentarme en el blando sillón de mi escritorio y, ayudado de la fantasía, redactar la monografía de un pueblo primitivo, del cual he divisado desde lejos algunos individuos sin molestarme sensiblemente; en lugar de llevar la vida miserable de un salvaje, en contacto íntimo con el indio, observándolo con criterio y estudiándolo metódicamente. Pero ese tiempo en que se 'fabricaban', de semejante manera, tales y tantas descripciones fantásticas de las costumbres y tradiciones de los primitivos habitantes del globo, en que cada cual, de acuerdo con su sistema filosófico se imaginaba y redactaba el origen de la humanidad y su desarrollo en las centurias pasadas, como asimismo sus diferentes fases de cultura: ese tiempo, en que el diletantismo, siguiendo el arbitrario método evolucionista, dominaba en el campo de nuestra noble ciencia: ese tiempo, digo, ya ha pasado para no volver más. M. Gusinde, Cuarta expedición a la Tierra del Fuego, Publicaciones del Museo de Etnología y Antropología 4 (1/2): 24-25 (1924).

18 Stocking, 2011, op.cit., p. 338.

19 Ibid., p. 350. 
del mundo, subsumiéndolos en las clasificaciones evolucionistas, así como Lucien Lévy-Bruhl leía en Paris las obras araucanistas de Tomás Guevara, que le confirmaban la ausencia de una noción de "alma" en los "pueblos primitivos". ${ }^{20}$ Para Wittgenstein al menos, el problema estaba claro: la tarea de la antropología era "describir y no explicar", apuntando con atención a las "representaciones perspicuas" más que al falso problema de la verdad, falsedad o error del contenido de las creencias. ${ }^{21}$

Debemos a Rodrigo Cárdenas y Alfredo Prieto el llamar la atención sobre una escena paradigmática de la etnología cristiana en Tierra del Fuego. ${ }^{22}$ No está demás recordar, siguiendo el relato de Wilhem Koppers, ${ }^{23}$ la aparición del nombre de Dios -Watauinewa- como un deus ex machina en la escena de la producción etnográfica, un Dios que viene a alimentar las discusiones antropo-teológicas de las escuelas europeas. Gusinde señala que este nombre le aparece por primera vez en su segunda expedición a Tierra del Fuego (1921):

[...] estábamos, como de costumbre, reunidos una noche en un rancho alrededor del fuego. El más inteligente de los ancianos [Alfredo] explicaba el mito del diluvio y decía que era muy antiguo. Habiéndole preguntado por el autor de esta inundación tan grande, noté que se efectuó un cambio visible en sus facciones. De los presentes, unos callaron hasta cerrar la boca, otros respondieron evasivamente: ¡Quién sabe! Por fin, un anciano dijo: Watauinewa mandó esa mucho

20 Ver las menciones a Tomás Guevara en La mentalité primitive (Paris, 1922) y L'âme primitive (Paris, 1927) de L. Lévy-Bruhl. Por su parte, la escuela austriaca del método histórico-cultural parece haberse opuesto en bloque a las nociones de "prelogismo" primitivo propuestas por LévyBrulh. W. Koppers por ejemplo, en las conclusiones de su libro (Entre los fueguinos. Punta Arenas, 1997, p. 184) señala ¿no demuestran ser insostenibles y superfluos por lo menos en lo que refiere a los Yámana, construcciones como la mentalidad prelógica de los primitivos de LévyBruhl?.

21 L. Wittgenstein, Observaciones a La Rama Dorada de Frazer (Madrid, 1992), p. 53 y 66-68.

22 Cárdenas y Prieto, 1999, op. cit.

23 El relato de la tercera expedición de Gusinde, junto a Koppers, a Tierra del Fuego, fue publicado en Stuttgart (Alemania) en 1924, con el nombre Unter Feuerland Indianern. Fue traducido y editado en Chile en 1997 por la Universidad de Magallanes y el Programa Chile Austral de la Unión Europea. agua. Preguntando ¿quién era ese Watauinewa? No tuve contestación.... ${ }^{24}$

$\mathrm{Al}$ parecer, Gusinde no toma muy en serio este episodio, convencido por la opinión de investigadores anteriores como el reverendo Thomas Bridges -misionero anglicano que llevaba varias décadas en Tierra del Fuego y autor del diccionario inédito inglésyamana- quién había establecido que los Yaghanes no tiene Deidad Suprema, Dios o Creador, tampoco ninguna palabra en su lengua para algo así ${ }^{25}$ Hyades y Deniker de la Misión Francesa al Cabo de Hornos (1882-83) que señalan respecto a los yaganes: no creemos poder modificar nuestra opinión sobre la ausencia de sentimiento religioso entre los fueguinos. Nosotros los hemos observado muy atentamente desde este punto de vista durante el año que hemos pasado entre ellos: nunca pudimos escuchar la menor alusión a un culto así, ni a una idea religiosa ${ }^{26} \mathrm{o}$ el viajero Charles W. Furlong, informado como muchos por Thomas Bridges, quién señala tajante que no tienen Dios ni palabra para nombrarlo, careciendo de los mas elementales atributos de las razas... jefatura y religión. ${ }^{27}$

En su tercera expedición (1922) -la que Gusinde quería realizar en compañía del mismísimo padre Schmidt, quien finalmente delega su representación

24 M. Gusinde, Tercer viaje a la Tierra del Fuego, Publicaciones del Museo de Etnología y Antropología de Chile 2 (3): 417-436 (1922), p. 429. Ver también Koppers, 1997, op. cit., p. 123 y Gusinde, 1986, op. cit., pp. 1011-1015. En esta última versión, además de identificar claramente al anciano Alfredo como su principal interlocutor en esta escena, Gusinde señala que Chris responde a la pregunta: "Watahuinewa es como el Dios para los cristianos" (p.1011)

25 J. Cooper, Analytical and Critical Bibliography of the Tribes of Tierra del Fuego and Adyacent Territory, (Washington, 1917), p... El mismo John Cooper señala en su bibliografía analítica sobre Tierra del Fuego (más de seis cientos autores) no haber encontrado evidencias de la creencia en un "ser supremo" (en ibíd.). Gusinde acusa reiteradamente la negligencia de los misioneros y especialmente de Thomas Bridges como causa del desconocimiento de la "vida espiritual" de los yámana (cf. Gusinde, 1986, op. cit., pp. 142-143, 312313, 1009-1010).

26 P. Hyades y J. Deniker, Mission scientifique du Cap Horn 1982-1983, 1891, p. 253, cit. en Gusinde, 1986, op.cit., p. 1008, quién muestra que muchos de los comentaristas se basaban en los informes de Thomas Bridges.

27 Ch. W. Furlong, The Alaculoofs and the Yahgans, the World's Southernmost Inhabitants, Proceedings Second Pan American Scientific Congress, Washington DC, 27 de diciembre 1915-8 de enero 1916, p. 231. 
en Wilhem Koppers- la creencia en Watauineva entre los yámana se confirma y se representa como un hallazgo excepcional. En palabras de Koppers: [Los yámanas] se revelaron como poseedores de un monoteísmo tan antiguo, tan claro, bien definido $y$ vivo que el descubrimiento de ello constituye un hecho sensacional, importante y significativo en el campo de la investigación de las religiones comparadas de nuestro tiempo. ${ }^{28}$ Exultantes con el "descubrimiento", y preocupados de transformar esta aparición de Dios en un hallazgo científico comprobado y contrastado, Gusinde y Koppers multiplican las consultas a los yámana y también a otros misioneros.

De la importancia extraordinaria del descubrimiento de los conceptos de la fe en Watauinewa entre los Yámanas, pronto nos hemos dado cuenta. Pues se trata de los fueguinos que Darwin ha presentado siempre en todo el mundo como un ejemplo particular del ateísmo total y primitivo. $Y$ frente a eso, la creencia en un ser supremo tan claro y seguro como hoy día se sabe de pocos pueblos primitivos. Era entonces nuestra obligación natural de tratar de aclarar este asunto con el mayor cuidado. Al principio, nosotros mismos preguntamos a la gente: ¿De donde lo tienen ustedes, les era propio o lo han adoptado de los misioneros cristianos? Esta pregunta tuvo siempre la misma respuesta: 'Eso no lo hemos aprendido de la misión, lo hemos tenido desde siempre. ${ }^{29}$

Gusinde ya le había manifestado anteriormente a Koppers la sospecha sobre una influencia misionera cristiana en la formulación de la idea monoteísta, por la pobreza de referencias que recogía al respecto. ${ }^{30}$ Sumado a las reiteradas negaciones de la posibilidad de una idea religiosa entre los yámana, la intuición de Koppers respecto a una inspiración divina en la "ética yámana" no tenía asideros muy claros, y como dice él mismo, esta materia había permanecido para los blancos como un libro reservado con siete sellos. ${ }^{31}$ Persistentes en la necesidad de descartar toda posibilidad de origen cristiano en la formulación yagán del Dios único, los religiosos austríacos someterán su hallazgo a la discusión con el anciano misionero anglicano John Lawrence:

28 Koppers, 1997, op.cit., p. 18.

29 Ibid., pp. 132-133.

30 Ibid. p. 124

31 Ibid.
[...] cuando me presenté donde ese caballero de edad y muy amable, con los resultados logrados hasta ahora sobre la fe de Watauinewa. En el principio se mostró muy impactado sobre nuestros descubrimientos no esperados y opinaba: 'Ya estoy aquí 53 años y jamás he escuchado algo sobre eso'. Yo le contesté: 'Eso puede ser, pero ahora se trata de establecer qué es lo que sucede con esta cosa': '¿es un bien original o transmitido por el cristianismo?'. Por favor, examinemos juntos, usted domina el idioma Yámana, los nombres del ser altísimo como también los dichos con los que esa gente se dirige a él[...] 'Ni los nombres, ni las fórmulas de las oraciones revelan de alguna manera la proveniencia de un idioma cristiano. Todo causa una legítima impresión de originalidad'[...] El buen caballero descubrió pronto que en las oraciones y dichos aparecían palabras y giros que ya no son usados en las conversaciones cotidianas[...] Es natural que el caballero anciano aprovechó la oportunidad de hablar él mismo con los aborígenes sobre Watauinewa. El resultado siguió siendo el mismo. A los Yámanas les es propia desde un comienzo una fe monoteísta clara y segura. ${ }^{32}$

En los tres volúmenes del segundo tomo dedicado por Gusinde a los Yámana entre Der Feuerland Indianern (1937), el autor reconoce en varias oportunidades la importancia decisiva que tuvo la participación de Nelly Lawrence, la mujer yámana casada Fred Lawrence, nativo de Tierra del Fuego e hijo del reverendo John Lawrence. Ella será recordada y homenajeada como la artífice de muchos de los hallazgos etnográficos o, como gusta decir Gusinde, de "la conquista del tesoro espiritual" de los fueguinos, por medio de toda la red de contactos yaganes facilitados por Nelly y que permitieron la producción de todo el corpus literario, mítico y ritual registrado, y también la producción del secreto que implica el hallazgo del nombre de Dios por los etnógrafos católicos.

A pesar de haber traducido varios evangelios en lenguas fueguinas, los evangelizadores anglicanos habían renunciado a una traducción de la idea monoteísta occidental a la lengua local, asumiendo que ni la lengua ni la cultura habían podido producir una idea religiosa o concepto del "ser supremo". El esposo anglo-fueguino de Nelly Lawrence, interrogado respecto a Watauinewa por los austríacos, les

$32 \quad$ Ibid., pp. 132-133. 
señaló: 'sí, eso ya lo he sabido desde hace tiempo, sin embargo no me he preocupado detalladamente del asunto, a lo que le observan '¿Pero porqué no lo ha dado a conocer?' A ello contestó Fred Laurence con toda razón: ‘Pero señores, cómo puedo saber aquí del interés que en Europa se tiene por la religión de los fueguinos?. ${ }^{33}$ Los católicos aceptan esta explicación, asumiendo que el problema era efectivamente europeo, y que lo apartado del mundo de esta región explicaba incluso que el tema no hubiera sido objeto de conversación entre el evangelizador europeo y su hijo nativo. Sin embargo, Koppers se apura en subrayar que la labor de los misioneros entre los Yamana debe ser considerada deficiente, ${ }^{34}$ por su incapacidad para interesarse en las creencias y religión de sus evangelizados, y usar esos conocimientos para una evangelización mas exitosa. La crítica de Gusinde a esta deficiencia "metodológica" de los misioneros, que Koppers atribuye a su falta de educación y preparación, se extenderá más personalmente al misionero Tomás Bridges, quién, a pesar de toda una vida en territorio fueguino, tampoco habría sido capaz de detectar la presencia de un monoteísmo originario indígena ni observar y entender ninguna de las instituciones religiosas, rituales y mitológicas de los indígenas:

[...] era evidente que las investigaciones de Bridges no nos ofrecían una imagen clara y exhaustiva de la cultura espiritual de los Yámanas. Así, para mencionar solo un aspecto, ni siquiera ha mencionado el nombre de la institución secreta del rito de la iniciación de la juventud y menos aun ha informado respecto de su contenido y su espíritu. La investigación de los Yámanas adolecía por lo tanto de grandes vacíos. ${ }^{35}$

Estas apreciaciones se insertan en una crítica más global de Gusinde la política de las misiones, tanto anglicanas como salesianas, documentando su responsabilidad en lo que hoy se discute si fue un genocidio o una política de cautiverio masivo de mujeres y niños para su disciplinamiento, uso y muerte. ${ }^{36} \mathrm{Al}$ sólido expediente que elabora en torno

33 Ibid, pp. 133-134.

34 Ibid.

35 Ibid., p. 123. Cf. tb. Gusinde, 1986, op.cit., pp.1009-1010.

36 J. Bascopé,Antes de la ley. Salvajismo y comercio sexual en Tierra del Fuego y Patagonia austral, J. Pavez y L. Kraushaar (eds.), Capitalismo y pornología (San Pedro de Atacama, 2011), y Bajo tuición. Infancia y extinción en la historia de la colonización fueguina Corpus 1 (1): 1-16 (2011b). a las prácticas mortales de los misioneros sobre el cuerpo yagán (la alimentación, la vestimenta, el encierro en viviendas cerradas, la sedentarización, el trabajo forzado y la propagación de epidemias como causas del exterminio) ${ }^{37}$, Gusinde sumará una crítica personal a Tomas Bridges, la que hace eco a la crítica de los mismos yámana:

[...] nunca recibió una educación sólida, ni siquiera había cursado por completo la escuela primaria. Además, creció y pasó toda su vida en un ámbito sumamente limitado [...] Bridges no era querido por los indígenas como persona. Muchos lo eludían debido a su porte autoritario y se mantenían alejados de la misión para no tener que renunciar a su valioso patrimonio cultural... ${ }^{38}$ [Con una] desconsiderada voluntad exterminadora [de la cultura] Bridges no se ganó una buena reputación entre los sensibles aborígenes; todos le temían[...] Para sus instituciones de importancia vital y para sus costumbres ancestrales, que les eran venerables, Bridges sólo tenía palabras ofensivas y despreciativas, y los amenazaba con introducir reformas sin miramientos si no las abandonaban[... ${ }^{39}$

Así, la personalidad e influencia del patriarca de las misiones anglicanas no sólo habría impedido que otros misioneros pudieran conocer la religión indígena, ${ }^{40}$ sino también habría obstaculizado la mención de Watauinewa por el temor de los nativos a ser reprimidos, exponer su Dios a la crítica y burla de los cristianos, y ser obligados a "olvidarlo todo". ${ }^{41}$ El nombre de Dios, palabra antigua vuelta secreto en contra del olvido, pasa a ocupar el lugar de la "superstición", indicio tyloriano de las "supervivencias" atávicas y de la coexistencia de tiempos, coexistencia que anglicanos, misioneros y evolucionistas, querían desaparecer para instaurar el tiempo único del Dios cristiano. ${ }^{42}$ En el fondo, Gusinde actuaba como sepulturero de este proceso, cuando los cuerpos yámana han sido sometidos y reducidos, y en la muerte del pueblo, invoca al espíritu religioso, la "vida espiri-

37 Gusinde, 1986, op.cit., pp. 299-320.

38 Ibid., pp. 142- 143.

39 Ibid. pp. 312

40 Ibid., p. 163.

41 Koppers 1997, op. cit., p. 134.

42 Cf. A. Menard, El exterminio como patrimonio, Ponencia en Jornadas de estudio "Formas del colonialismo nacional", 14-15 de diciembre 2011, Museo Regional de Magallanes; y G. Didi-Huberman, L'image survivante (Paris, 2002), pp. 51-70. 
tual" como vida post-mortem, lo que queda de los yámana. Se evidencia así la producción etnográfica del secreto por el gesto mismo de su revelación, metáfora del traspaso de la soberanía de un cuerpo colectivo (como una sociedad secreta) a un corpus etnológico, donde la "espíritu" queda registrado en el momento que abandona el cuerpo físico.

De informante de las disputas globales de la antropología, el padre Gusinde se vuelve así un crítico de los misioneros que viven en territorio de colonización y hablan la lengua indígena, intentando comprobar que los yaganes conservaron durante más de 50 años el secreto de una creencia monoteísta, ante los extranjeros y sus hijos nativos (Lucas Bridges, Fred Lawrence) quienes, a pesar de manejar perfectamente la lengua y tener acceso a ciertas nociones desconocidas para los europeos, no se habrían interesado en analizar y dar a conocer los secretos de la cultura. En resumen, es toda la estrategia evangelizadora, la falta de preparación etnográfica $y$, en el fondo, el desinterés evolucionista anglicano por la alteridad religiosa, lo que están cuestionando los etnólogos de la escuela histórico-cultural. ${ }^{43}$

A esta polémica de histórico-culturalistas austríacos contra evolucionistas anglicanos subyace una tensión que nos parece clave para cualquier relectura de la antropología indigenista fundadora, la dicotomía entre los paradigmas iniciáticos y los paradigmas dialógicos de la producción etnográfica. ${ }^{44}$ El "descubrimiento" que relatan Gusinde y Koppers corresponde a un relato épico de la iniciación del etnógrafo en los secretos nativos, la "apropiación" o "conquista" de un "tesoro espiritual" (son los términos preferidos por Gusinde), resaltando así sus propios méritos como descubridores de la cultura, frente a agentes anglófonos aculturadores que no habrían sabido conocer, entender y valorar estos secretos. Al mismo tiempo, el nativo hijo de misionero anglicano Lucas Bridges le critica a estos y otros etnólogos precisamente lo contrario, un exceso de dialogismo, en una interlocución hecha de negociaciones e in-

43 Sobre la diferencia de concepciones misionales entre anglicanos y católicos en Tierra del Fuego, ver J. Bascopé, 2011b, op.cit, y para el caso mapuche A. Menard y J. Pavez, Mapuche y anglicanos (Santiago, 2007) y Pudor y raza en la pornología araucanista, Anales de desclasificación 2(1).

44 J. Clifford, Poder y diálogo en etnografía: la iniciación de Marcel Griaule, Dilemas de la cultura. Antropología, literatura y arte en la perspectiva posmoderna (Buenos Aires, 1995), pp. 78-118. tercambios que habrían hecho posible, ya no solo la captura de un secreto, sino la producción de la representación etnográfica como puro espectáculo. ${ }^{45}$ Detengamosnos entonces brevemente en los días de la revelación del secreto tal como lo relata Koppers, uno de sus protagonistas.

Un día de enero, conversando con cuatro mujeres yámana en la "lavandería", un galpón de la estancia fueguina de la familia Lawrence, volvió a aparecer el nombre de Watauinewa. Cuando los investigadores inquirieron más sobre este nombre, se generó "un gran desconcierto" entre las mujeres presentes y "ninguna contestó". Ante la insistencia, la vieja Mary se decidió y dijo: "Watauinewa like God, like Christian God' ${ }^{46}$ señalando también lentamente y reprimiendo repetidamente fuertes emociones que Watauinewa enviaba la muerte de ciertos niños como castigo. Ante esta reacción, similar a la que había visto Gusinde unos años antes en torno a este tema, Koppers señala que cada vez era más evidente que aquí yacía algo oculto que por algún motivo no quería salir a la luz. Los austríacos solicitaron a las mujeres que piensen juntas cuando y como nos podrían contar lo demás de lo que saben sobre Watanuinewa y se alejaron. Unos días después, Nelly Lawrence, la esposa yagan de Fred Lawrence, invitó nuevamente los sacerdotes a su lavandería, donde Adelaida y ella les contarían "todo sobre Watauinewa". Ahí se enteraron que ellas dos no habían perdido hijos, por lo tanto "podían hablar libremente" de Watauinewa, lo que no era el caso de las otras mujeres que se sienten castigadas por él y no quieren que se hable de él en su presencia. Acto seguido a la explicación del tabú, Adelaida y Nelly comenzaron a mencionarnos los distintos nombres que se emplean para Watauinewa, el ser altísimo, nombre que Koppers identifica como "el nombre oficial y propio" que significa "el muy viejo, el eterno". Ya desatada la conversación en torno al "señor alto allá arriba", las mujeres

45 Para una defensa del proyecto civilizador de Lucas Bridges entre los selk'nam, a partir del relato autobiográfico de este héroe iniciático, ver J. Bascopé, La vida civil en El último confín de la Tierra (ms. 2012).

46 En inglés en el original (W. Koppers, Unter FeuerlandIndianern, Stuttgart, 1924, p. 142; también en inglés en Gusinde, 1986, op.cit., p. 1012). En Koppers, una página antes, es Alfredo quién da la misma respuesta, que el autor traduce al alemán: Watauinewa ist wie der Gott der Christen (ibid., p. 141). 
informaron los diferentes nombres dados a Dios, ${ }^{47}$ y algunas fórmulas de oración cortas con las que se acostumbra a dirigirse a Watauinewa. Con el tiempo estas oraciones sumarán más de sesenta y serán clasificadas en cuatro tipos por los sacerdotes etnógrafos: oraciones de lamentación, de ruegos, de agradecimiento y "dichos de naturaleza neutral". 48

Llegados a este punto, hay que subrayar varios aspectos de esta extraña escena de la revelación del nombre de Dios. En primer lugar, destaca el protagonismo de una mujer yagán, nuera del misionero John Lawrence, y que por lo tanto está en una posición de permanente mediación y traducción entre los anglicanos blancos y los yagán. El mismo Koppers retrata a "la señora Lawrence" en posición destacada en su capítulo de "caracterizaciones individuales" de ciertos personajes yagán, los que son en el fondo los "informantes claves" de Gusinde. A este título, Nelly Lawrence participa como co-autora etnográfica de la investigación ${ }^{49}$ y constituye para los austriacos una evidencia más de la existencia de verdaderos individuos entre los yagán, en contra de la teoría elaborada en Europa en torno a una mesa de juego sobre los fueguinos como masa indiferenciada carente de individuos. ${ }^{50}$ La representación etnográfica produce aquí la emergencia de individualidades en la escena de revelación de un secreto (la existencia de Dios como ser supremo), que es a la vez producción y descubrimiento oportuno para los mismos Yámana, cuando se afirma el sujeto de la traducción como efecto de la representación

47 Watuwa: "cuento antiguo"; Hitapuan: "mi padre de arriba"; Hauimun: "padre terrenal"; Monauanakin: "el altísimo"; Abailakin: "el todopoderoso"; Kelaiechon: "el viejo bueno allá arriba"; Watauinewa - esaku: "el duro como roca"; Watauinewa - sef: "el muy viejo allá arriba en el cielo". En una obra tardía, Gusinde invierte el orden de importancia de las denominaciones del Dios "único", quedándose con el de Hidabuan, antes que el de Watauinewa: De todos los fueguinos, los Yámanas son los que tratan con más confianza a su Dios y le llaman casi siempre 'Hidábuan' = 'nuestro padre'. Otras designaciones dicen significativamente: 'Watauinewa' = 'el antiquísimo', 'Manunákin' = 'el único poderoso', 'Watauinewa-sef' = 'el viejísimo allá en el cielo', 'Wölapatuch' = 'el gran asesino', 'el que da muerte a los hombres' (Gusinde 1951, op.cit. pp. 321-322).

48 Koppers 1997, op.cit., pp. 124-127; Gusinde, 1986, op.cit., pp. 1026-1046.

49 Koppers, 1997, op.cit., pp. 177-178; Gusinde, 1986, op. cit., pp. $172-173$ y 189 .

50 Koppers, 1997, op.cit, p. 175. teológica y política. A la vez, permite la profundización de la reflexión yagán sobre la traductibilidad del espíritu, siendo este traducción Watahuineva = Ser Supremo el resultado de un particular agenciamiento de las mujeres yámana en la etnografía gusindiana.

El relato de iniciación que propone Koppers tiende a construirse como relato dialógico, donde las mujeres se vuelven protagonistas de la representación e iniciadoras de los etnógrafos. Al contrario de su experiencia con los selk'nam donde primaron los informes de hombres, entre los yámana Gusinde registró principalmente a mujeres, especialmente en la documentación de la literatura oral, obtenida con mujeres como Julia -esposa de Alfredo y principal narradora de los mitos- Nelly -esposa de John Lawrence y principal "organizadora" de la investigación en terreno-, Adelaida, Gertie, o las ancianas Mary y Peine. Como bien destacó Johannes Wilbert, el protagonismo femenino en la producción de los relatos míticos, las caracterizaciones culturales y el conjunto de informaciones etnográficas levantadas, muestran que estas mujeres con las cuales Gusinde pasaba gran parte del día supieron agenciarse al laboratorio etnográfico puesto en práctica por el etnógrafo, logrando inscribir en el texto ciertas perspectivas propias de la posición de las mujeres en patriarcado yagán, especialmente las informantes de edad avanzada que podían trasgredir ciertas normas de género, otorgando por ejemplo un acento en las costumbres y comportamientos sexuales, mostrando así una posición ambivalente respecto al tabú, los secretos y las parodias rituales de la religión. ${ }^{51}$ Esto implicó un mayor peso de las relaciones dialógicas en el proceso de iniciación de los etnógrafos, así como una agencia internacional y multilingüe de las mujeres, habilitadas así al protagonismo en el funeral etnológico facilitado y observado por Gusinde. La individualización de Dios por la traducción, la producción de una "palabra referida" en el diálogo de géneros, permitirá la emergencia de la individualidad yagán en el texto, por una etnografía cuyos acentos iniciáticos no logran recubrir la escena de producción dialógica. Esto lleva directamente a un segundo problema, el de la revelación del secreto o levantamiento del tabú como hazaña heroica de los etnógrafos "degeneracionistas". La narración

51 J. Wilbert (ed.), Folk literature of the Yamana Indians (Washington, 1976), p. 6-8. 
del descubrimiento del nombre de un Dios único, pre-existente a la empresa misionera, constituye un giro epistemológico que rompe con todas las políticas y prácticas de traducción de la expansión cristiana. En efecto,

[h] ay al menos tres grandes políticas o decisiones de traducción que la Corona española y la Iglesia católica romana ponen alternativamente en práctica - y a veces de manera yuxtapuesta-en lo que atañe a los textos religiosos (Biblia, Catecismos, Sermonarios, etc.) durante los primeros siglos de la llamada 'Conquista espiritual' del 'Nuevo Mundo': 1. No es posible traducir las verdades de la santa fe cristiana a las lenguas de los indios, ergo, prohíbese la traducción y, para la evangelización, oblíguese a los nativos a aprender la lengua de Castilla; 2. Es necesario y hasta cierto punto posible traducir las verdades de la fe cristiana a dichas lenguas, pero los nombres propios y las nociones claves del cristianismo han de permanecer intactas, en castellano, en tales textos; 3 . Es necesario y aun posible traducirlo todo, nombres y nociones complejas incluidas, ocupando vocablos preexistentes en tales lenguas. (Cualquiera fuera el caso, de cierto, siempre habrán operado mecanismos de control administrativo: concilios, sínodos y otras instancias de revisión, aprobación o rechazo, de tales traducciones). ${ }^{52}$

La elección entre una y otra alternativa dependerá alternativamente de la influencia y poder que irán consiguiendo históricamente congregaciones e iglesias más involucradas en la empresa evangelizadora. Durante la primera mitad del siglo XX, varios misioneros-etnógrafos se jugaron decididamente por la tercera opción, la traducción del nombre de Dios en la lengua de los conversos. Es el caso por ejemplo del misionero protestante francés Maurice Leenhardt, para quién, según el detallado estudio de James Clifford:

Dios tenía que tener un nombre vernáculo [...] o mas bien tenía que cooptar el término genérico usado para los dioses y espíritus tradicionales. Sino, designado por una palabra extraña y extranjera, el Dios cristiano podía ser simplemente añadido a la lista de divinidades como primus inter pares. Otros misioneros, por ejemplo, Patteson, Codrington y

52 Andrés Ajens, El tabernáculo quebrado: desclasificando a dios y/o al diablo, Anales de desclasificación 2 (1) (en prensa). la Misión Anglo-Melanesia, habían optado por el vocablo europeo 'God'. Temían los malentendidos inevitables envueltos en la adaptación de un nombre pagano. Pero Leenhardt creía que una cierta confusión era parte de cualquier proceso de cambio y educación; y a menos que los términos nativos pudieran ser traídos a nuevas significaciones no habría conversión real. ${ }^{53}$

Mientras que la adopción de una palabra indígena podía llevar a "malentendidos" e incluso a confusiones embarazosas para el pudor cristiano, ${ }^{54}$ el uso del nombre europeo conllevaba el peligro de sumar una nueva divinidad al panteón de espíritus y deidades pre-existentes, no logrando imponerse el Dios (de los) cristiano(s) por encima de estos otros. En el primer caso, los sentidos figurados de la traducción y la amplitud semántica de los conceptos nativos jugaban en contra de la unidad y singularidad absoluta que se buscaba significar en el Dios único, abriéndose así el espacio para el "deslizamiento de sentido" entre la generalidad y la unicidad del término

53 James Clifford, Person and Myth. Maurice Leenhardt in the Melanesian World (Durham \& London, 1992), p. 80.

54 Ajens (op. cit. 2011) reporta el caso de la palabra Tupä por la cual se traduce Dios en guaraní generando amplios debates en los siglos XVI y XVII: Las palabras sometidas a consideración de teólogos, traductores y teólogos-traductores son, al cabo, cuatro: Tupá [o Tupã], que en el Catecismo traduce (a) 'Dios'; Tubá [o Tuba], que en el Catecismo está por (Dios) 'Padre'; Tayrá [o Ta'yra], por (Dios) 'Hijo' (de Dios); y Membyrá [o Membyra], por (Dios) 'Hijo' (de la Virgen) - en estos dos últimos casos, siguiendo la doble nominación de la filiación en guaraní, masculina o femenina, según sea el caso. Para [el obispo del Paraguay] Cárdenas, los dos primeros vocablos simplemente son 'nombres propios de Demonios', el tercero significa 'polución y esperma del varón', y el cuarto, 'hijo [h]avido por fornicación, y cópula carnal con el varón, y junta de su humor'. Para resolver el embrollo, Arturo de Montoya propondrá una descomposición del concepto para afirmar que Tupä (Tu-pä) vendría a traducirse correctamente por “Qué es eso?”, la exclamación del asombro ante lo sublime incognoscible... Clifford por su parte (1992, op. cit., p. 87) recuerda que los predecesores de Leenhardt habían traducido "Biblia" como "el contenedor de la palabra", hasta que descubrieron que los isleños también llamaban a sus estuches peniales 'contenedores de la palabra' (asociado seguramente a las potencias creadoras de "la palabra"). En cuanto la evangelización en África, Iracema Dulley, analiza con detalle el proceso por el cual se llegó a enunciar la fórmula "Suku onganga" ("dios es fetichero") como una manera de posicionar a Dios entre las fuerzas que operaban los poderes del fetiche en la religión bantú (Deus é feiticeiro. Práctica e disputa nas missoes católicas em Angola colonial. Sao Paulo, 2010, p. 135-143) 
que se quiere propio de Dios ${ }^{55}$. En el segundo, se requería un esfuerzo especial dedicado a la definición de los caracteres de Dios para hallar la traducción que más acumulara e indexara significados en torno a un significante que se impusiera por sobre todos los demás. Para esto, habría que hallar un nombre genérico que pudiera volverse el nombre propio de Dios, o un nombre propio cuya singularidad pudiera traducir la generalidad de lo numinoso.

Leenhardt por ejemplo, empieza a experimentar con los canacas una traducción, tentativa y provisional, con el nombre "bao", que podía significar "espíritu mágico", "cadáver humano", "persona muy anciana", "ancestro fallecido", "fundador", "divinidad olvidada", "tótem que se ha confundido con un ancestro". ${ }^{56}$ La adaptabilidad del concepto connotativo de los linajes de jefaturas masculinas, la preferencia de los conversos por este vocablo, y su potencial asociación dualista con otra fuente de autoridad -la autoridad totémica asociada a la idea de flujo y traducida como "dios largo"- llevaron a adoptarlo, e intentar "capitalizarlo como nombre propio". ${ }^{57}$ Por su parte, el misionero portugués Carlos Estermann relata una anécdota que muestra el débil resultado de la operación inversa intentada por los misioneros protestantes entre los hereros de Angola del Sur:

Procurando un término que significase a Dios, los misioneros [de la Sociedad Renana] pensaban haberlo encontrado en la palabra Mukuru. Etimológicamente quiere decir viejo, anciano, y se empleaba para designar el espíritu de un antepasado, y particularmente de un jefe de aldea. No tardó mucho en que un misionero se halla desengañado de manera drástica. Amenazando un viejo centenario con los castigos de Dios (Mukuru) este exclamó: ¿pero acaso no soy yo el Mukuru de mis súbditos? Y furioso expulsó el misionario del círculo de sus chozas [cubatas]. Entretanto los misioneros venían notando que los Herero empleaban muchas veces la palabra compuesta Kalunga-Ndyambi para designar un ser misterioso. Un día cuando uno de ellos le preguntó a un viejo quién era Kalunga-Ndyambi, obtuvo esta respuesta que disipó todas las dudas: 'Es el mismo al que ustedes llaman Mukuru' ${ }^{58}$

55 Dulley, ibid., p. 140.

56 Clifford 1992, op.cit., p. 87

57 Ibid. p. 89.

58 C. Estermann, cit. en Dulley 2010, op.cit., pp. 135-136.
Esta anécdota angoleña grafica el intento misionero de rescatar un término genérico ("anciano") para capitalizarlo como nombre propio, mientras que los nativos realizaban su propia operación de traducción entre un nombre propio y el nombre genérico usado por los misioneros. El caso nos acerca bastante a lo que ocurrió en Tierra del Fuego con los etnógrafos austríacos, en una operación donde se impone un sentido predefinido de los caracteres divinos (antigüedad, invisibilidad, omnisciencia, omnipresencia, omnipotencia) y las relaciones con el Dios único (sumisión, oración, resignación) que los etnógrafos del monoteísmo estaban prestos a encontrar en el lenguaje del otro. Esta revelación se muestra así como un efecto dramático del relato de los descubridores, que viene a alimentar la épica de la escuela histórico-cultural por medio de una fórmula ya no de traducción difusionista, sino de equivalencia universalista de un evolucionismo "al revés". El momento del yemalasemoina, "gran ceremonia funeraria" por la muerte de un niño, se vuelve la ocasión para observar lo que se quiere ver: las características cristianas del dios indígena. Luego de un yemalasemoina al que asiste con Gusinde, Koppers escribe:

[...] su creencia en Watauinewa se encontraba realmente muy dentro del corazón de esta gente. Aquí se reveló de que era una convicción segura y firme y que todos la tenían. Con eso se manifestó también que reconocen la omnipotencia de Watauinewa, su omnipresencia, su derecho de propiedad indiscutible sobre todo lo visible, su grandeza inalcanzable que nadie puede tocar, y al fin el desamparo y la impotencia de la criatura humana que se encuentra enteramente subordinada a su poder, no pudiendo hacer valer ante él ningún derecho [...] el espíritu Yámana no está sujeto en lo único. También sabe reunir la totalidad de los hechos mundiales en uno, adjudicándola a una causa general, el ser altísimo Watauinewa [quién] es considerado el dueño supremo y real de la naturaleza y de la vida, incluida la del hombre. ${ }^{59}$

Gusinde por su parte redacta las siguientes observaciones en el informe de su cuarta expedición, publicado el mismo año que la crónica de Koppers:

A ese Ser Supremo lo respetan con suma veneración porque él domina todo; de él provie-

59 Koppers 1997 op.cit., p. 143 y 183. 
nen todas las leyes y disposiciones, las buenas costumbres y preceptos que rigen a esos indios; él quiere que todos cumplan sus mandatos y, como lo ve todo, castiga, casi siempre con la muerte muy temprana, a los que no los observan; porque él es muy fuerte y contra él ningún otro poder es capaz. El es un espíritu puro, y no tiene ni tuvo cuerpo; nadie puede verle, a pesar de que el está presente en todas partes; él existía ya mucho antes que los primeros pobladores Yaganes y él no muere jamás. De él son todas las cosas, porque él las ha hecho [...] Tales son, en síntesis, las ideas religiosas de nuestros Yaganes, las que, como se comprende, jamás les han sido comunicadas por misioneros europeos; al contrario, el uso de términos y frases ya muy anticuados que expresan y usan en las ceremonias de luto, son pruebas convincentes por sí solas ya, de que constituyen un patrimonio que poseen desde antaño. 60

Como profecía auto-cumplida, los etnógrafos encuentran lo que querían encontrar: un Dios (casi) en todo idéntico al Dios cristiano. El hallazgo no se presenta entonces como el resultado de una traducción dialógica sino como una perfecta y transparente equivalencia en la experiencia teológica: Watauinewa "like Christian God", aunque luego se llame Hidabuan u otro, es el Dios único que está detrás de estas palabras escondidas a los misioneros, como "supersticiones" secretas, tabuizadas por la muerte de los niños. Todo ocurre como si el relato heroico de la iniciación en los secretos de la cultura (el paradigma iniciático de la representación etnográfica), intentara esconder la producción dialógica del nombre de Dios como "palabra referida". Para Bajtín, la "palabra referida" (la palabra que introduce un afuera en un adentro del discurso, que es la condición de posibilidad del diálogo y del habla misma ${ }^{61}$ ) es la que produce el abismo del sentido, una "mise-en-abyme" por la cual el lenguaje se mantiene vivo, en movimiento, abierto

60 M. Gusinde, Cuarta expedición a la Tierra del Fuego. Publicaciones del Museo de Etnología y Antropología 4 (1/2), p. 16 (1924).

61 Speech within speech, utterance within utterance, and at the same time also speech about speech, utterance about utterance, M. Bajtin/ V. N. Voloshinov, Marxism and the philosophy of language, cit. en D. Carrol, The alterity of discourse: form, history, and the question of the political in M.M. Bakhtin. Diacritics 13 (2), p. 70 (1983). al (lo) otro. 62 Este abismo, análogo al "a-archivo" de todas las traducciones del que habla Ajens, es efecto y consecuencia de la dialogía en el lenguaje y su heteroglosia constitutiva. ${ }^{63}$ Esta noción de lenguaje abierto y en transformación se opone en todo a la idea de sacerdotes-lingüistas que ven el lenguaje como sistema cerrado para la contemplación, produciendo contenedores (sarcófagos) de la verdad de la palabra (diccionarios, gramáticas), que instauran la lengua como cadáver sin uso, y transforman el discurso en extensión de la autoridad. ${ }^{64} \mathrm{Al}$ igual que los vestigios

62 La palabra en la conversación viva está directamente, descaradamente, orientada hacia una futura palabra de respuesta: provoca una respuesta, la anticipa y se estructura a sí misma en la dirección de la respuesta. Formada en la atmósfera de lo ya dicho, la palabra es al mismo tiempo determinada por lo que no se ha dicho aún pero que es requerido y de hecho anticipado por la palabra respondida. M. Bajtin, The Dialogical Imagination (Austin, 1981), p. 280. Sobre la "exotopía" del discurso en Bajtin, su orientación constitutiva hacia el afuera, cf. P. De Man, Diálogo y dialogismo, La resistencia a la teoría (Madrid, 1990), pp. 163-175; sobre la denegación de una condición dialógica 'originaria', de la supresión de las huellas de las otras voces en cada voz" y el discurso monológico como "extension de la autoridad, cf. Carrol, 1983 op. cit., p. 69-71.

63 El a-archivo, archivo sin archivo de todas las traducciones, trocas y mudanzas, es decir, de todo, si tal hubiera, se dejaría traducir por La biblioteca de Babel y a la vez la traduciría. Pero. Solo en cuanto, subrayando su temporal índole, deja entrever como tales sus sueños o "axiomas" de eternidad ('La biblioteca existe ab aeterno', J L. Borges), Ajens 2011, op.cit.. El abismo de la traducción entonces como el quiebre dialógico de la palabra, la palabra referida por uno en la palabra del otro, en una eternidad que no está atrás de la palabra, en la biblioteca (colonial) de Babel, sino delante de ella, en el archivo por venir, el a-archivo de lo que va a quedar en el juego de sus connotaciones. La última palabra del mundo y acerca del mundo no ha sido pronunciada todavía [...] todo está aún en el futuro y estará siempre en el futuro (M. Bajtin en D. Lodge, "Después de Bakhtin", en Varios autores, La lingüística de la escritura. Debates entre lengua y literatura, Barcelona, 1989, p. 104).

$64 . .$. el pensamiento lingüístico europeo se formó y maduró en su interés por los cadáveres de la lengua escrita; casi todas sus categorías básicas, sus perspectivas y técnicas básicas se desarrollaron en el proceso de revivir esos cadáveres (Voloshinov/Bajtin, cit. en Carrol, 1983 op.cit., p. 69). Similar a estos sacerdotes-lingüistas es el trabajo del estructuralista Lévi-Strauss, cuyas Mitológicas conciben al mito como sistema cerrado y definido, inerte y sin uso, presto a ser disecado. Para una crítica a esta subsunción de la secuencialidad, de la dialogía y de la performatividad de las narrativas mitográficas, cf. B. Manheim Hacia una Mitografía Andina, en J. C. Godenzzi Alegre (ed.), Tradición oral andina y amazónica (Cuzco, 1999), pp. 47-79. 
arqueológicos, sobre la lengua momificada se afirma la autoridad del filólogo-intérprete, que escribe en representación de aquello que ha muerto. Como si los nombres de Dios ya existieran antes del diálogo que lo hace posible, como si ese abismo dialógico debiera ser contenido por una Biblioteca de Babel donde estarían ya escritas todas las equivalencias del nombre de Dios, medida de todas las palabras y las cosas.

El contrato de (re)presentación: política y economía del intercambio en la relación etnográfica

Mientras que la narrativa iniciática de la etnografía está destinada legitimar la extracción y "conquista" de los documentos secretos de la cultura (el "tesoro espiritual") y reforzar así su posición en un sistema colonial mundial de producción y acumulación científica (división internacional del trabajo); la dimensión dialógica de la representación etnográfica no puede entenderse sin analizar las formas de intercambio y prestaciones a las que deben acceder los etnógrafos en su relación con los informantes de la cultura que quieren representar. Las redes de informantes y el sistema intercambiario que se establece en torno al laboratorio etnográfico en terreno constituyen entonces la dimensión complementaria de la división internacional (¿taylorista?) del trabajo etnológico. En su relato sobre la institución del gabinete etnográfico gusindiano, el visitante metropolitano Koppers describe cómo las expediciones de Gusinde se apoyan en el la señora Nelly Lawrence para reclutar informantes, recabar documentos orales y colectar informaciones, por los cuales paga lo que se le pida.

La historia del registro del "canto del duelo" o talauwaia es esclarecedora en este punto. Koppers señala haber logrado grabar unas treinta canciones entre los yámana, y solo les faltaba el canto del duelo, el que nadie quería cantar debido a la profunda tristeza que lo inspiraba. Koppers y Gusinde señalan comprender la objeción indígena, ya que

[...] el sentimiento de dolor es la condición previa para este canto de duelo [pero, señala Koppers] finalmente logramos poder grabar para la ciencia el canto de duelo. Lo debemos a la intervención de Fred Lawrence [...] cuando escuchó que aun faltaba el canto del duelo, solicitó este a su esposa, la buena señora [Nelly] Lawrence, que nos ayudara también en este caso a obtener lo que pretendíamos. La señora Lawrence prometió hacer lo posible, sin embargo tenía sus dudas sobre el resultado del plan. El 20 de Marzo nos avisó en la mañana que dos mujeres, Gertie y Peine, habían declarado estar dispuestas de colaborar. Pero les sería muy difícil y este duelo afectaría tanto su corazón que sería necesario una recompensa. Nosotros deberíamos ofrecer a cada una de las mujeres por lo menos veinte pesos argentinos, entonces probablemente podrían cantar ese canto fúnebre[...] Nosotros conocíamos a nuestros grandes niños Yámana. No pretendían en este caso una extorsión. Pero la señora Lawrence aprovechó esta oportunidad, pues las necesidades de los miembros de su tribu son también las propias. A Gertie y más aún a la anciana solitaria Peine les sería muy difícil adquirir un vestido nuevo. Naturalmente prometimos darles lo que deseaban y Fred Lawrence, con la amabilidad que le caracteriza, por su parte ofreció un regalo especial, si ellas lo hacían bien. ${ }^{65}$

La demanda de prestaciones, monetarias y otras, por parte de los "informantes", y la aceptación de un (con)trato de intercambio por parte de los investigadores, no deben aquí extrañar. De hecho, hay que celebrar que estos contratos hayan quedado registrados por los expedicionarios, ya que en muchos casos, la épica heroica de la iniciación etnográfica tiende esconder las prestaciones y compensaciones que la hacen posible. ${ }^{66}$ Aunque, como hemos mostrado en otros trabajos, es cada vez mas evidente que no existe don ni gratuidad en la relación etnográfica en la medida que está siempre en juego una producción que origina una representación, política o descriptiva. ${ }^{67} \mathrm{El}$ contrato de representación etnográfica y el intercambio que este autoriza pueden adquirir diferentes formas: económicas o políticas, materiales o simbólicas. El caso de Tomás Guevara en Araucanía ofrece un notable ejemplo de ejercicio político que implica de parte del etnógrafo ceder un lugar en el texto para el nombre propio y la autoría de los miembros de ciertas familias mapuche que ofrecieron sus relatos nütram. Además, incluye la protección y padrinazgo de los jóvenes de estas familias para que tengan espacio

65 Koppers 1997, op.cit., pp. 138-139.

66 Cf. Clifford 1995, op.cit.

67 J. Pavez, Fetiches kongo, momias atacameñas y soberanía colonial. Trayectoria de Gustavo Le Paige (1903-1980), Estudios Atacameños 44 (2012); J. Pavez, 2003, op.cit. 
en las instituciones educativas chilenas; $e$ incluye sin duda compensaciones materiales para las familias o colaboradores que lo necesiten. ${ }^{68}$ De esta manera, se trata de un contrato de representación que implica protección material y reconocimiento político, lo que permitirá más tarde al mismo Guevara legitimar su autoridad etnográfica ante el muy metropolitano $e$ tyloriano etnólogo anglo-chileno Ricardo Latcham, señalando que era imposible conocer el alma de los aborígenes[...] si [uno] no se ha hecho indio, por lo menos hasta cierto punto. ${ }^{69} \mathrm{Al}$ parecer, es también ese grado de reconocimiento e intercambio que logró Gusinde entre los yaganes, a pesar de haber siempre estado, aunque muchas veces, de paso, como se observa en los discursos de reencuentro al inicio de la tercera temporada en Puerto Mejillones, cuando los expedicionarios convocan a un "consejo directivo" para informar sobre los objetivos de esta tercera misión: participar y registrar la ceremonia de iniciación chiejaus y la ceremonia secreta masculina kina:

Gusinde estimó que había llegado el momento oportuno para pronunciar un discurso. En su calidad de miembro de la tribu le asistía el pleno derecho para ello. Las personas más influyentes: Calderón, Chris y Santiago entienden lo suficiente español para poder seguirlo. Escuchan primero alabanzas, loas y reconocimiento por todo lo que nos han aportado hasta ahora con confianza y la ayuda que nos han prodigado para el logro de nuestro propósito. Nosotros estamos muy satisfechos con ellos y les expresamos nuestros agradecimientos. Y ese agradecimiento lo hemos manifestado ya en repetidas ocasiones. Ellos recibieron cosas para su uso, vestuario, tabaco $y$ en especial sus propias fotografías. ${ }^{70}$ Pero más

68 Pavez 2003, op. cit.

69 Veinticinco años entre los araucanos[...] me habían habilitado para conocer a fondo las peculiaridades de estos indígenas", T. Guevara, Chile Prehispánico, cit. en Luis Carlos Parentini, Introducción a la etnohistoria mapuche (Santiago, 1996), p. 37.

70 Desde su segundo viaje, Gusinde se preocupa de llevar copias de las fotos que produce en sus expediciones y regalarlas a los yámana. Como él mismo señala, esto le granjeó la confianza de los fueguinos. Cf. Gusinde, 1986, op.cit., p. 188. Sobre la producción y circulación de las fotografías de Gusinde en sus viajes a Tierra del Fuego, y la importancia de Nelly Laurence en la escenificación de las fotografías, ver M. Palma, Un caso fotográfico a la luz de los viajes de Martin Gusinde a Tierra del Fuego (1918-1924), Revista chilena de antropología visual 6: 102-114 (2005). importante que todo eso era lo que mi compañero tenía intenciones de continuar haciendo, defender ese pequeño territorio que los Yámanas aún tienen aquí. Porque también en esto se han visto amenazados y el peligro de perderlo, como bien lo saben, aún no ha sido conjurado. Pero él está dispuesto de hacer todo lo posible, también en el futuro, para que este daño sea evitado. Esta intervención en favor de ellos la realizaría con la mayor alegría en caso de que ahora, cuando se trata de festejar la Kina, nosotros volveríamos a gozar de la plena confianza y una acogida favorable de parte de ellos. Esta alocución no dejó de tener su efecto, pues provocó un fuerte aplauso y también una sonrisa de agradecimiento y de satisfacción en las caras de cada uno de ellos. Calderón hizo en seguida uso de la palabra y dijo al inicio: 'Si, tú tienes la razón. Todas las promesas las has cumplido fielmente. Tú no eres como los otros blancos. Estos también nos hacen promesas, pero no las cumplen. Tu eres realmente un Yámana (un hombre). Lo que ustedes en lo sucesivo deseáis de nosotros, lo que quieren escuchar y ver, todo eso será hecho. Rogamos solo que mandéis, estamos totalmente a vuestro servicio' ${ }^{71}$

Entre lo que "mandó" el yámana Gusinde, y que en realidad consiguió en base a incentivos, está la realización de la ceremonia kina, la que había perdido el favor de los yaganes: La Kina no está muy arraigada entre los Yámana. Y tampoco les agrada este teatro de pavor. Eso lo atestigua que la Kina ha estado durmiendo durante 30 años y seguramente no habría sido sacada del olvido si nosotros no lo hubiéramos solicitado... Para la mayoría de los asistentes al Kina, Gertie prepara la comida en su casa, que naturalmente es costeada por nosotros. ${ }^{72}$ Hay que señalar que gracias a la insistencia y financiamiento de los etnógrafos, como efecto de esta demanda de representación etnográfica quedó un completo registro de la última ceremonia kina producida en la historia de la sociedad yagán. ${ }^{73}$

71 Koppers 1997, op.cit., p. 45.

72 Ibid, p. 105

73 Cf. Gusinde, 1986, op.cit., pp. 1286-1358. El hijo nativo del misionero anglicano, Lucas Bridges, apelando, como en otras ocasiones, a una idea de "autenticidad" nativa de la cual él mismo reclama la autoridad de la representación, formula así sus críticas a la producción de ceremonias por 
En este contexto, se vuelve relevante el contenido del canto del duelo, que los etnólogos católicos consiguieron grabar a cambio de una prestación monetaria. Como señalamos más arriba, el canto fue improvisado por dos mujeres, la joven Gertie y la anciana Peine, las que se prepararon durante varias horas para entonar un texto que parece más una reflexión, amarga, sobre el fin de la sociedad yagán, la paulatina desaparición de sus parientes y familias, e incluso, lo más notable quizás, una lectura de la propia escena dialógica de la producción etnográfica del canto. Es decir que, luego de su resistencia inicial a desarrollar la "performance" artística, las dos mujeres decidieron transformar la situación en una oportunidad para una representación política de la avanzada situación de descomposición demográfica de la sociedad yagán. De esta manera, el canto tradicionalmente interpretado en funerales individuales fue transformado en el canto fúnebre del fin de una colectividad, y el documento cultural que expresaba la afectación por la desaparición de un individuo se volvió un documento político que hablaba por toda una comunidad de destino fatal. Primero cantó Gertie y declamó Peine el texto que sigue:

¡Oh, qué pobre somos que estos dos [Gusinde y Koppers] nos obligan a cantar el Talauwaia [el canto del duelo]. Ellos vienen de un pueblo que es muy numeroso y nosotros somos tan pocos. Los pocos que quedan de nosotros son como pocos pajaritos que por casualidad han podido escapar al cazador. Y Watauinewa nos ha quitado los buenos, solo los feos y despreciables quedan hasta estos últimos días del pueblo de los Yámana. Los malos, y nosotros los enfermos quedamos hasta hoy [...] Tanta gente que había antiguamente en el oeste. Ahora quedamos solo dos o tres. ${ }^{74}$

encargo: El avance de la civilización puso en descubrimiento el secreto de la logia, tan celosamente guardado por innumerables generaciones. Las mujeres se enteraron del engaño y los indios fueron inducidos, mediante algún dinero, a representar sus comedias ante auditorios de científicos. He visto fotografías en que los actores aparecen con pelo corto y pintados como nunca lo estuvieron en mis tiempos (Bridges, 1952, pp. 438-39, cit. en Cárdenas y Prieto, 1999, op.cit.). Bridges reconoce no haber escuchado nunca de un Dios supremo por parte de los yámana, y otorga el crédito del descubrimiento de un secreto, pero inmediatamente reduce la "revelación" etnográfica a una mascarada o representación ad hoc para científicos y sus tecnologías de registro.

74 Koppers, op.cit., 1997, pp. 139-140.
Luego, los etnógrafos les solicitan que cambien de roles. Entonces cantó Peine y Gertie declamó:

Esos dos vinieron y nos hacen cantar aquí Talauwaia. Aunque hace mucho tiempo que no hemos repetido este canto, ambos lo desean. Otras veces ha sido Watauinewa quién nos ha obligado a cantar este canto debido a alguna desgracia. Ahora lo desean ambos. Los blancos pensaban hasta ahora que esto seria solo una especie de juego, pero para nosotras es un canto muy serio [...] Si todos mis parientes murieran, yo también tendría que sufrir como un hombre. Y yo entonces trabajaría como ellos en el bosque, en el mar, etc. [...] hasta que también sucumbiera. De mis parientes solo quedan mujeres; los hombres de mi parentela, él los ha tomado. Yo no soy como las mujeres viejas de mi pueblo. Ellas cantaban y hablaban muy bien y de manera muy hermosa [...] Y todas las bellas palabras se nos han perdido y estamos obligadas tan frecuentemente a hablar en inglés y español. Así olvidamos nuestras antiguas y bonitas palabras Yámana. ¡Oh que pobre somos ahora! [...] ¡Que pocos somos! [...] $]^{75}$

Koppers deja constancia de su emoción al rescatar estos "documentos" "hablados bajo un fuerte estímulo pasional". Al lograr la empatía de los austríacos, estas mujeres yámana estaban también contribuyendo a la representación política de la sociedad fueguina en descomposición, ya que Gusinde nunca cejó en sus esfuerzos por asegurarle a la comunidad yámana un territorio reconocido por el Estado en Puerto Mejillones. La etnografía de los yámana fue también el producto de esta representación política que los indígenas reconocieron en Martín Gusinde. Sin embargo, las mujeres están diciendo algo más: estos dos [Gusinde y Koppers] nos obligan a cantar el Talauwaia (Peine), otras veces ha sido Watauinewa quién nos ha obligado a cantar este canto [...] Ahora lo desean ambos (Gertie). Es decir que en estas declamaciones, los sacerdotes etnógrafos vienen a ocupar la lugar de Watahuinewa, el espíritu que exige el canto del duelo como responsable último de la muerte de los niños.

La forma en que Peine y Gertie encaran el Talauwaia solicitado por los etnógrafos no está sin relación con la manera en que estos últimos

75 Ibid, p. 140 
buscan validar la autenticidad de los documentos culturales, buscando no las versiones autorales de los personajes sino la producción de versiones canónicas de las narrativas en base a una simulada unanimidad cultural. Aquí también se trata de apuntar ya no a la captura de voces individuales, sino a la producción de una suerte de voz colectiva, que subsume las versiones y variantes personales en una narrativa maestra llamada a dar valor de autenticidad y legitimidad al trabajo etnográfico de Gusinde. Para este, la autenticidad implica un acuerdo unánime que es también según él, una forma de conciencia: si hay varias personas reunidas, y el visitante extranjero formula una pregunta, todos los presentes participan en la solución, al menos en sus reflexiones, intercambian pareceres y se ponen de acuerdo acerca de una única respuesta que posee valor auténtico. ${ }^{76}$ Sin embargo, Gusinde no señala que este trabajo grupal y la búsqueda de una respuesta única está también determinada por su desconocimiento del idioma de los narradores, y la necesidad de formar grupos de intérpretes que le ayudarán en la tarea de registro. Esto explica que los informantes de Gusinde no estén explícitamente asociados a informaciones o relatos específicos, salvo en casos en que se desliza, casi a su pesar, la importancia de ciertos personajes para ciertos aspectos centrales, como el corpus mítico contado por Julia, el conocimiento ritual de Alfredo o el conocimiento chamánico ofrecido por Masemikens. Sin embargo, Gusinde tendrá un acercamiento diferente con la narrativa selk'nam que recogerá después, y para la cual identificará claramente a cada relator (Wilbert, p. . Como él mismo señala que la investigación con los yámana fue estableciendo el modelo de trabajo para el despliegue en las otras etnias (p. 189), se puede pensar que la orientación de la investigación fue cambiando desde una búsqueda de la unanimidad y una menor individuación (yámana) a una mayor individuación autoral y menor unanimidad cultural (selk'nam).

En cualquier caso, no debe extrañar ni escandalizar que el intercambio (de dinero, de fotografías, de alimentos o de gestiones políticas) haya permitido conocer el secreto de la sociedad secreta (kina) ya que en todas estas, el secreto es algo que siempre se puede negociar, algo que de-

76 Gusinde, 1986, op.cit., p. 185. be ser producido como secreto para existir como tal. Muchas veces, es precisamente un contrato (de compra-venta u de otro tipo) lo que se quiere mantener en secreto. ${ }^{77}$ Como escribió hace tiempo Elías Canetti, el secreto es un elemento de la potencia, es lo que ocurre al interior de un cuerpo, el soberano está siempre al tanto de la calidad de los recipientes a los cuales confía sus secretos, de la confianza que puede otorgarles, y está en condiciones de estimar cuales de esos recipientes está muy lleno y podría desbordar. ${ }^{78} \mathrm{Al}$ entregar sus secretos al "recipiente" etnográfico gusindiano, ${ }^{79}$ los yámana están quizás consumando el fin de su soberanía, y la penetración de su comunidad por la lógica inmunitaria que representa el etnógrafo misionero del rescate. En la lógica inmunitaria los yámana convienen en contratos de intercambio y la soberanía deviene en representación. Estamos ya lejos del diagrama disciplinario en donde Gusinde es informante de Smith, y las mujeres yámana (Nelly, Gertie, Peine, Adelaida, Mary, Julia) son informantes de Gusinde, Koopers o Hornbostel. La representación se ha trasladado a otra dimensión, la de la derrota soberana y la venta del secreto, condición de la disciplina y fin del cuerpo soberano, Watahuineva es sustituido por Dios como suplemento del origen, producido a posteriori como representación para sí de la muerte del colectivo.

Este encadenamiento de posiciones y subordinaciones en la división colonial del trabajo de representación se encuentra en muchos casos, lugares y dimensiones. Así también, los conceptos indígenas atraviesan repúblicas y océanos y, atrapados en el diagrama soberano, siguen las rutas de la acumulación hasta las metrópolis científicas para alimentar las máquinas de generalización universalista del aparato disciplinario. Así, un texto de teoría

77 Es el caso de las sociedades secretas afro-cubanas que hemos estudiado en otra parte (cf. Pavez, Africanismes à Cuba. Textes, images et classes, Paris, 2007).

78 Elias Canetti, Masse et puissance (Paris, 1966), p. 311.

79 Koppers subraya haber obtenido el permiso del "consejo directivo" yagán para tomar anotaciones durante los varios días de la ceremonia kina, algo que le había sido negado a Gusinde en la ceremonia chiehaus de su viaje anterior. El autor señala que este permiso fue conseguido por estar ausente el "viejo Alfredo" que se había opuesto al registro en la ocasión anterior (1997, op.cit. pp. 45-46). Gusinde en cambio señala que esta autorización fue posible por haber él mismo sido iniciado en el chiehaus anterior. 
fundamental como Las formas elementales de la vida religiosa se basa casi en una sola etnografía, la de los arunta australianos por el etnógrafo Spencer y el administrador Gillen, quienes identifican los usos del objeto churinga, el cual, introducido en la teoría parisina, servirá tanto a Durkheim como a Lévi-Strauss para sus diagramas disciplinarios. ${ }^{80}$ $Y$ aunque las interpretaciones del churinga fueran invención de un arunta amigo de Gillen, y el concepto fuera aislado de la cadena conceptual de la cual es extraído, su rendimiento será exponencial cuando es redefinido en el marco de esquemas clasificatorios disciplinarios, permitiendo afirmar la total soberanía del teórico de Paris o Londres -llámese Tylor, Frazer, Durkheim, Mauss, o Lévi-Strausssobre las definiciones particulares o monografías descriptivas "de caracteres esenciales" que exige Durkheim a sus informantes, nativos o etnógrafos, para la producción desde el centro metropolitano de la teoría general de la cultura o la "generalización nomotética" (Durkheim) compuesta de "hechos de funcionamiento general" (Mauss). ${ }^{81}$

\section{Infancia primitiva: los niños en la división interna-} cional del trabajo de representación

Llegados a este punto se vuelve pertinente introducir nuestra tercera y última reflexión, sobre la relación entre la producción de conocimientos antropológicos y la infancia indígena, que es también el problema de la relación entre los niños nativos, la soberanía colonial y la disciplina científica. Existe sin duda una relación epistemológica entre el proceso de aprendizaje de la generalización por los niños,

80 Georges Stocking, The Ethnographer's Magic. Fieldwork in British Anthropology from Tylor to Malinowski, The Ethnographer's Magic and Other Essays in the History of Anthropology (Madison, 1992), pp. 12-59.

81 Tanto Durkheim como Weber critican la formulación de "generalidades". Para Durkheim, la acumulación y exceso de generalidad es pre-científica (literaria, intuitiva, carente de método) y solo la monografía de "caracteres esenciales" permite generalización nomotética. Cf. Jean-Louis Fabiani, La généralisation dans les sciences historiques. Obstacle épistémologique ou ambition légitime?, Annales. Histoire, Sciences Sociales 62 (1): 9-28 (2007). Para Levi-Strauss, lo universal está condicionado por la distancia, en la medida que solo la distancia en el tiempo y el espacio permite la generación de un pensamiento universal (el que parece desarrollarse siempre en Paris...). Cf. Johannes Fabian, Le Temps et les autres (Paris, 2006). el disciplinamiento de la infancia, la instauración o pérdida de soberanía política y la etnografía de la colonización. Hemos estudiado diferentes casos de relaciones entre misioneros, antropólogos y niños indígenas, las que parecen siempre constituir un núcleo del problema del poder del agente colonial. Es decir que, con la aplicación de los diagramas disciplinarios sobre la infancia, la captura de lo que se concibe como la "materia prima" sobre la cual se aplican los dispositivos pedagógicos de la cultura, se alimenta la producción de soberanía etnográfica, entendida como la sujeción a una ley del Estado, monárquico o republicano. En un trabajo sobre el sacerdote Gustavo Le Paige, hemos documentado la importancia de los niños de San Pedro de Atacama no sólo como informantes y mano de obra barata para el trabajo de excavación arqueológica, sino también como agentes de propagación de la soberanía misionera, cautivos del poder disciplinario e instrumental de la arqueología, y agentes de trasmisión de la evangelización, la que parece ir junto a contratos de intercambio con el misionero arqueólogo, contratos por los cuales se compran y venden objetos fetichizados y mano de obra infantil. ${ }^{82}$ Por ser significantes inestables de la diacronía y del paso del tiempo, opuestos a los adultos y la identidad fósil, los niños encarnan la oposición entre lo vivo y lo muerto, lo estable y lo inestable, como garantes de una temporalidad colectiva. ${ }^{83}$ Los niños exorcizan la muerte, por lo que se vuelven el eslabón clave en la promoción de un etnocidio, cristiano o republicano. Como se ha visto en diferentes momentos de la crónica de Koppers, para los yámana los niños son también las primeras víctimas del "dios" Watauinewa, y la muerte de un hijo funda el tabú del nombre de Dios. Mientras que la vida del niño expresa la diacronía de la comunidad, su muerte y aquél que la causa son marcados por la prohibición de ser nombrados.

Coincidentemente, la importancia que Gusinde otorgó a los niños parece haberle facilitado el conocimiento del tabú y su rompimiento. Watauinewa como significante de la muerte de niños viene a ocupar el mismo lugar fatídico que el Estado y las misiones que hicieron imposible la antigua vida

82 Pavez 2010, op. cit.

83 Giorgio Agamben, Enfance et histoire. Destruction de l'expérience et origine de l'histoire (Paris, 2002 [1978]). 
yagán. ${ }^{84}$ El etnólogo a su vez viene a revelar el tabú por el cual se esconde el causante de las muertes, Watauinewa o el "hombre blanco". Esta coincidencia hace pensar que el nombre de Dios podría también ser, precisamente, el nombre de la soberanía que "da la muerte", el muy etnocida Christian God por medio de sus fieles cristianos y especialmente sus misioneros y sacerdotes. No por nada, al declamar el Talailawa, Gertie y Peine ponen en primer plano la causa de ese llanto, sustituyendo explícitamente a Watahuineva por los sacerdotes etnógrafos. La interrupción de la historicidad yagán, que es obra de la etnología des-historizante pero también del imperialismo ecológico y la soberanía colonial, se expresa en la muerte de los niños como lo que va quedando de lo que va a desaparecer. Detrás de las "supersticiones" que fundan el tabú, se encuentra la "supervivencia" y aquello que la amenaza: "Watauinewa like Christian God" es también el enunciado de una denuncia contra la violencia colonial cristiana.

84 Desde los años 80 del siglo XIX, los yaganes habían sido reducidos a menos de un tercio de su demografía (de 1000 a 300 habitantes) como efecto exclusivo de la fundación de la ciudad de Ushuaia por la División Expedicionaria del Atlántico Sud del Estado argentino (1884), la instalación de los funcionarios de Estado en ella, y las epidemias de sarampión, viruela e influenza que se decimaron rápidamente a la población yagan (Thomas Bridges, Censo de las tribus 1884, Los indios del último confín (Ushuaia, 2001), p.135; J. Bascopé, La vida civil en El último confín de la Tierra (ms. 2012), cita a Lucas Bridges, hijo del anterior, que menciona un total de 3000 yaganes antes de la hecatombe, quedando 300 yaganes vivos a finales de los 80; para el censo de Thomas Bridges, 3000 personas conformaban el conjunto de los pueblos fueguinos en 1884, aunque sus crónicas muestran que las enfermedades asechan ya antes de 1880). La misión anglicana no parece haber tenido el mismo grado de responsabilidad en el genocidio yagán, como la tuvieron las misiones salesianas para el exterminio de los selk'nam (de los cuales sólo quedaban 500 representantes hacia 1884), para el cual las evidencias indican que el cautiverio en las misiones implicaban una muerte segura para los niños (Gusinde da importantes detalles de la afectación mortal de los intentos civilizadores de los misioneros, mientras que el salesiano Borgatello se mistificaba en la observación contemplativa de la muerte de los niños). Por otra parte, mujeres y niños selk'nam fueron también masivamente entregados en cautiverio para el servicio doméstico y la crianza entre familias de Punta Arenas. Todo esto se suma a la violencia de la colonización ganadera que avanza sobre la isla grande de Tierra del Fuego, empujando a los sobrevivientes selk'nam hacia el sur de esta. Cf. J. Bascopé, op.cit, 2011a, 2011b y 2012.
El Dios cristiano y sus misioneros es el que se lleva a los niños y pone fin a la historicidad.

En una obra de síntesis de su etnología en Tierra del Fuego, publicada en los años 50, cuando sus ocupaciones etnográficas ya habían migrado hacia el África Central, Martín Gusinde sincera lo que considera algunas de las claves para una aproximación exitosa al objeto de estudio.

Lo diré en dos palabras: también sus corazones se conquistan irremisiblemente valiéndose de los niños; lo mismo que hacemos con los adultos en nuestras propias patrias. Desde que los Selknam del Río del Fuego notaron mi predilección por los niños, abandonaron toda su primera desconfianza; saber mis sentimientos los desarmó completamente e hizo que me consideraran amigo. El primitivo aprecia mucho más la buena y sincera voluntad que se le dispensa a sus pequeñuelos, que la que se manifiesta a él mismo. Por temperamento me agradan mucho los niños. Las mas encantadoras horas que pasé en la Tierra del Fuego fueron para mi las de convivencia con aquellas pequeñas y confiadas criaturas. Con los muchachos participaba en sus juegos y bromas, olvidándome de mis años. Esto les agradaba extraordinariamente. Me pedían reiteradamente que formara parte de sus filas y de sus corros, que participara en sus bromas y burlas... Durante todo el día saltaban y jugaban los alegres y animados niños a mi alrededor, cuando no me encontraba ocupado en otra cosa; no me dejaron nunca tiempo para cavilaciones melancólicas o para el desaliento, al ver que mi investigación no progresaba con arreglo a mis deseos. Feliz y tranquilo me sentí de nuevo niño dentro de la vigorosa y alegre juventud india. ${ }^{85}$

Gusinde es explícito al reconocer la utilidad instrumental de esta afinidad con los niños, como paso hacia un contrato de colaboración con los adultos, que son el fin último de sus intereses disciplinarios, a diferencia de los misioneros anglicanos, de un sacerdote católico como Le Paige, o incluso de un profesor como Tomás Guevara trabajados todos por la motivación de "civilizar al indio" a partir del disciplinamiento pedagógico orientado específicamente a la infancia.

Después de varias semanas de estancia en aquel campamento capté casualmente la obser-

85 M. Gusinde, 1951, op.cit., pp. 137-138 
vación de una india anciana que hablaba a sus compañeros de tribu sobre mi, diciéndoles: 'Este Koliot tiene que ser una buena persona porque juega de forma cordial con nuestros niños'. En efecto, por medio de los niños me gané la confianza de los Selknam, así como la de los Yamanas y Alacalufes. Para confirmar la eficacia de esta afirmación, debo añadir que por este medio he triunfado indefectiblemente en otras partes del sur y del norte de América. Sin embargo ni la postura espiritual anteriormente descrita frente a los primitivos ni el poder utilizar la suficientemente explicada mediación de los niños, integran por sí solas al verdadero investigador. Ante todo tiene que haber recibido del buen Dios, así como de su posición social, la necesaria vocación. ${ }^{86}$

Cuando publica estas páginas, Gusinde ya estaba entregado a la sublimación de la infancia en la apariencia infantil de los pigmeos del Congo y Venezuela, los que compartirían con los fueguinos una excepcionalidad racial expresada en su morfología física y su antigüedad ontogenética, ${ }^{87}$ las que Gusinde quiere relacionar con un correlato religioso-cultural. La dimensión teológica se vuelve así una clave de la excepcionalidad racial y cultural: por una parte, se confirma el monoteísmo de grupos considerados como remanentes raciales de la más antigua humanidad (los que propone llamar "twides"), diferenciándolos así de los llamados "Negros" que considera bajo la influencia de la magia, el animismo y el manatismo; ${ }^{88}$ y por otra, reafirma la inmunidad teológica de los grupos pigmeos ante las influencias animistas de los "vecinos negros", transformando esta común inmunidad monoteísta en una prueba de la unidad

86 Ibid., p. 137.

87 Considero la totalidad de los twides de Africa tropical como una raza única y muy antigua, un caso aislado; las características raciales típicas y la estructura básica de su tipo cultural son las mismas en los tres super-grupos; forman una unidad somatológica y cultural. M. Gusinde, cit. en E. Bourguignon. Review of Die Twiden, Pygmäen Und Pygmoide Im Tropischen Afrika, Martín Gusinde, 1956. American Anthropologist 60 (1958), p. 180. Recordemos que en los años 20 en Chile, Gusinde ya se había convencido que "los yaganes pertenecen al grupo de los pigmoideos". Cf. Gusinde, 1922, op. cit, p. 432.

88 Martín Gusinde. Pygmies and Pigmoids: Twides of Tropical Africa. Anthropological Quaterly 28 (1): 3-61 (1955), pp. 32-34 histórica de los grupos pigmeos. ${ }^{89}$ Gusinde va aún más allá en su idealización católica de la excepcionalidad pigmea, al observar el "alto desarrollo" de la moralidad entre los pigmeos, "particularmente de la moral sexual", viendo una estrecha relación entre el desarrollo de la moralidad como control social y la presencia de Dios en la vida cotidiana de los grupos..$^{90}$ Se trata entonces de una unidad física que significa una unidad moral: monoteísmo, defensa de la propiedad privada, monogamia; por lo que no es casualidad que el etnógrafo misionero encuentre excepcionalmente concentrados todos estos valores cristianos en grupos de rasgos físicos excepcionales, biogenéticamente anteriores a toda forma de "comunismo primitivo". ${ }^{91}$ En esta etnología, el cuerpo pigmeo, por su antigüedad bio-antropológica, se vuelve el signo de una reserva moral de la humanidad, algo que un cristiano también podría decir de la inocencia del cuerpo infantil. Esto explica la importancia que adquiere la antropología física que Gusinde había practicado sobre los fueguinos, y que la Misión Científica Chilena para el Estudio del Indio Fueguino (1946) profundizará en los años en que el austríaco reali-

89 La actitud de todos los twides hacia el animismo y el manatismo es similar, pero distintivamente diferente a la de sus vecinos negros. Es esta común actitud que ofrece la prueba de la unidad histórica de estos grupos ampliamente dispersos. Un número de informes publicados confiables de las últimas tres décadas muestran la actividad religiosa de todos los grupos Twide culminando en el culto de un Ser Supremo sobrenatural. Este Ser asume un lugar dominante en su fe y otras actividades cuasi-religiosas son parte de este culto [...] W. Schmidt (1933, p. 491) ha colectado el abundante y ampliamente diseminado material, y se ha logrado información adicional sobre la religión de los Twides desde 1933. Ibid., p. 33.

90 Ibid., p. 34.

91 Gusinde también viaja entre los bosquimanos de Sudáfrica (bushmen y hottentotes conocidos como "pueblos amarillos" diferenciados de los hereros y bantú) para comprobar si forman parte de la gran familia twide que conoció en el Congo Belga y Ruanda. Ahí, se dedica a una antropometría que concibe como base para el argumento teológico-moral, ofreciendo descripciones detalladas de los cuerpos bosquimanos: La forma corporal de la raza bosquimana muestra claramente una notable adaptación a su medio desértico; el color claro de su piel combina bien con sus alrededores desérticos; su peso liviano, su estructura delicada, y sus largas piernas hacen posible prolongadas corridas en las arenas del desierto. M. Gusinde, Anthropological Investigations of the Bushmen of South Africa, Anthropological Quarterly 26 (1), p. 27 (1953). 
zaba sus estudios raciológicos africanistas. ${ }^{92}$ Para la antropología en Chile, se conjugaban así el valor de antigüedad de un cuerpo físico y el valor metafísico de una "espiritualidad" impracticable, sin que ningún cuerpo político ni individuo alguno pudiera ofrecer resistencia a la representación etnológica y nacional de la extinción fueguina.

Desde el siglo XVIII, fue un lugar común de las disciplinas evolucionistas pensar al hombre primitivo (los colonizados) como si estuvieran en el estadio evolutivo de un niño civilizado, consolidándose la relación discursiva entre "el salvaje como niño" y "el niño como salvaje". ${ }^{93}$ La equivalencia contribuye así a la "negación de co-temporalidad" que Johannes Fabian considera constitutiva de la relación de la antropología con sus objetos. Lévi-Strauss, en sintonía con Gusinde, propone invertir esta retórica, señalando que los "niños primitivos" muestran un espíritu más positivo y más maduro que los nuestros, lo que los acerca más al adulto civilizado. ${ }^{94}$ Sin embargo, recordemos que el mismo Lévi-Strauss se había dedicado a experimentar la violación del tabú del nombre propio entre los niños nambikwara, generando lo que Derrida llamó "una guerra de nombres propios", que muestra la relación de violencia que se reproduce en el acto de nominación, tabuización y rompimiento del tabú del nombre propio. ${ }^{95}$ La criminología y la psiquiatría mostraban por su parte y desde antes del siglo XX un interés importante en los niños, por su señalada inestabilidad como significante, moral, biológico y sexual: la infancia fue el principio de la generalización de la psiquiatría y su posibilidad de capturar a los adultos. ${ }^{96}$ Así, las disciplinas antropológicas parecen haber nacido afirmándose y alimentándose del cuerpo infantil, de su control y su ortopedia. Así mismo, como muestran Foucault y Ann L. Stoler, el origen del kinder garden está justamente asociado a la

92 Ver por ejemplo, A. Lipschutz, G. Mostny y L. Robin, The bearing of ethnic and genetic conditions of the blood groups of three Fueguian Tribes, American Journal of Physical Anthropology 4 (3): 311-322 (1946) y A. Lipschutz et al. Physical Characteristics of Fueguian, American Journal of Physical Anthropology 5 (3): 295-321 (1947).

93 Ann L. Stoler, Race and the education of desire. Foucault's History of sexuality and the colonial order of things (Durham / London, 1995). R. Bastide;

94 Lévi-Strauss, cit. en J. Fabian, Le Temps et les autres. Comment l'anthropologie construit son objet. (Paris, 2006), p. 116.

95 J. Derrida, De la grammatologie (Paris, 1967).

96 M. Foucault, Les anormaux. Cours au Collège de France 1974-1975 (Paris, 1999), p. 287. necesidad de separar el niño burgués y su sexualidad de las nodrizas y servidumbres indígenas, consideradas siempre como razas que contaminan y hacen peligrar la formación del cuerpo burgués. La teoría freudiana parece alinearse sobre este control burgués, al evacuar completamente las nodrizas o sirvientas domésticas indígenas del complejo edípico, al mismo tiempo que intenta explicar las formaciones sociales "primitivas" a partir de la psicopatología infantil..$^{97}$ A pesar de todo esto, no deja de sorprender el artículo del neurólogo Isidor Coriat, publicado en 1915, intitulado "Psychoneurosis entre tribus primitivas", en el cual, a partir de la lectura de los informes de Charles W. Furlong, propone una aplicación de la teoría freudiana de la psiconeurosis a las tribus fueguinas. ${ }^{98}$ Para explicar un ataque de rabia del cazador selk'nam Anihikin, quién había trabajado para los Bridges y también para Furlong como informante, capataz y "mano derecha", Coriat invoca la teoría elaborada por Freud en Totem y tabú, donde se entiende el tabú como una forma infantil de prohibición de un deseo, explicando así el comportamiento impulsivo del joven selk'nam, también mencionado aquí como cuadro histérico, por la falta de mecanismos de represión y substitución, ${ }^{99}$ mecanismos que serían propios de un estadio superior de civilización. En última instancia, Coriat interpreta la agresividad del informante y hombre de mano con su patrón y etnógrafo por un apetito sexual insatisfecho que sería consecuencia de una supuesta tradición de acumulación de mujeres jóvenes por los más ancianos de la tribu, lo que redundaría en soltería forzada o apareamiento de los jóvenes con las mujeres más viejas. ${ }^{100}$ Además de la equivalencia

97 R. Bastide, Le névrosé, l'enfant et le primitif, Sociologie et psychanalyse (Paris, 1950).

98 Isador $\mathrm{H}$. Coriat, Psychoneuroses among primitive tribes. The Journal of Abnormal Psychology 10 (3): 201-208 (1915). Coriat retoma en estas interpretaciones sicoanalíticas sobre los fueguinos en el capítulo tercero de su libro Repressed Emotions (New York, 1920). Furlong señala también que Coriat ha usado "sus datos sobre los procesos mentales" de los fueguinos, en op.cit. 1916, p. 232.

99 Ibid. p. 201.

100 El cazador Anihikin se había hecho temido por el asesinato múltiple de varias mujeres en un asalto al campamento de un clan vecino, por lo que más que de apetito sexual, la violencia que expresa Anihikin no se puede separar de las condiciones generales de violencia y desintegración histórica de la sociedad selk'nam en el contexto de colonización (cf. F. Fanon, Oeuvres, Paris, 2011; para mayores detalles sobre el caso, cf. Bascopé, op.cit., 2012). 
niño-hombre primitivo, encontramos aquí una cita que invierte la relación entre escritura y violencia que es el locus classicus de la antropología, y se presenta como lección de escritura, transformando la escritura en una suerte de música llamada a "calmar" a los niños-salvajes:

El Sr. Furlong señala como sigue: 'Estoy completamente convencido que una noche, mientras acampaba solo con los Onas en el corazón de los bosques fueguinos, mi mano derecha Aanakin, quién tiene una buena cuenta de homicidios a su haber, estaba rumiando sentado en su wigwam, el que estaba abierto hacia el fuego; me miró por cerca de una hora con una actitud y expresión que me recuerdan la mirada que tiene a veces un perro antes de morder [...] Era una mirada fugaz mitad de rabia y mitad de sorpresa, pero no le di el tiempo a su mente para quedarse en el mismo humor, ya que al mismo tiempo conseguí mi cuaderno y lápiz y empecé a dibujar animales y otras cosas con las que eran familiares. Les gusta mirarlo a uno dibujando y nombrar la cosa, y así los mantuve ocupados por quizás una hora, hasta finalmente sacarles carcajadas de risa. Estoy bastante convencido que me anticipé a un ataque o una predisposición para este.'101

A pesar de la singularidad de esta experiencia terapéutica, el artículo no logra despegar de la lógica de la ejemplaridad experimental del espécimen, dando un salto sin mediación entre este caso particular de un fueguino enojado con el explorador que lo contrata, y la generalidad de la neurosis en las tribus primitivas. De esta manera, el artículo que empieza señalando No es una ocurrencia poco frecuente entre los individuos Yahganes y Onas ser sujetos de repentinos estallidos de furor y violencia, termina entre sus conclusiones: Los individuos de rasgos mentales tan primitivos no han aprendido a reprimir exitosamente sus emociones y por eso son propensos a repentinos arrebatos emocionales. La sustitución y represión en las razas civilizadas son usadas para recubrir nuestras complejas y muy diversas maneras de expresar nuestros deseos y necesidades sociales. ${ }^{102}$

Aunque Tomás Guevara vivía en Araucanía, y había impartido enseñanza a numerosos niños

\footnotetext{
101 Ibid., p. 203-204.
}

102 Ibid., p. 207. mapuche, en una de sus últimas obras, invocará argumentos similares para generalizaciones que buscan transformar las singularidades en ejemplaridad científica serializada. Pero en vez de asociar estas neurosis violentas a un carácter racial y cultural puro, lo asocia a los efectos negativos inesperados de lo que llama "mestizaje", aunque en el fondo, se trata simplemente de imponer una jerarquía política y racial sobre quién fuera su alumno y luego importante contradictor, Manuel Manquilef:

Cuando se mezclan dos razas, una buena i otra mediocre, el producto tendrá menos de la primera i más de la segunda. Es lo que ha sucedido con los mestizos de la Araucanía [...]. Nos hemos valido de algunos cooperadores indígenas para averiguar la calidad de estas descendencias i hemos recibido datos de que están compuestos casi en su mayoría de sujetos bebedores, pendencieros, sin capacidad para el trabajo i con predisposiciones a las neuropatías [...] Los que se instruyen un poco adquieren la forma i exterioridad de la civilización que los rodea, pero en el fondo quedan agresivos en las palabras $i$ en los conceptos, reconcentrados i con una gruesa dosis de odio para los de la otra raza. Cuando escriben, son violentos i usan un naturalismo crudo i arrogante. Tratan por lo común cuestiones fáciles i de hecho sin elevarse en la disertación a las esferas del razonamiento superior. [Nota:] El tipo que por ahora podemos presentar de estas publicaciones es un folleto del normalista de raza don Manuel Manquilef, mestizo originario de Quepe, titulado Tierras de Arauco. ${ }^{103}$

Sin duda el pensamiento etnológico colonial no puede aceptar la violencia del otro como medio legítimo para fines legítimos, es decir, como consecuencia lógica de la misma violencia colonial, la que no permite que otro soberano actúe fuera de la ley creada por el derecho que impone y del cual se exime la soberanía colonial. Tampoco puede reconocer la violencia colonial en su historicidad, ya que debería cuestionar la adecuación de sus medios (violencia) en relación a sus fines (inmunidad). Las teorías de la emancipación afroamericana, desde Frederick Douglas a Frantz Fanon, y sus lecturas poscoloniales, de Edward Said a Paul Gilroy, mostraron claramente la importancia de la violencia

103 T. Guevara, La Etnología araucana en el poema de Ercilla (Santiago, 1918), pp. 287-288. 
en los procesos de emancipación anti-esclavistas y anti-coloniales, en la medida que la colonización opera una dialéctica donde el otro es absorbido en un derecho colonial siempre conservado con violencia. ${ }^{104}$ Franz Fanon especialmente estableció con claridad teórica y contundencia empírica la relación psychotizante de la violencia estructural que impone y reproduce la relación colonial, teoría que explica ampliamente tanto las miradas amenazantes de Anhikin a Furlong, los innumerables registros de la violencia inter-tribal fueguina, de colonos, militares, misioneros y aventureros en Tierra del Fuego, o el libro ¡Las tierras de Arauco! (1915) de Manuel Manquilef, ${ }^{105}$ un texto sobre la soberanía mapuche, que es sin duda el ensayo político más importante de la etapa reduccional en Araucanía.

Preocupados de completar la descripción del mapa de las clasificaciones étnicas donde los sujetos eran ejemplares de conjuntos homogéneos, anónimos y unánimes, las oficinas etnográficas debieron sin embargo lidiar con individualidades fueguinas, sujetos individuados que emergían de la representación etnográfica, y se resistían, a veces con violencia, a la subsunción en la clasificación etnológica o racial. Parte importante de la violencia etnológica consistió en concebir a los "grandes niños" salvajes como incapaces de producir abstracciones y generalidades, y por lo tanto, debían ser traducidos y representados, incapaces de representarse a sí mismos. Esto porque estarían mas cerca del carácter animal que de la cultura. En el caso fueguino, y ante el hecho de haber llegado después del desastre demográfico, la empresa de Gusinde y de la escuela de Viena se propuso reproducir esta infantilización, animalizando los cuerpos de las "razas" de cazadores y recolectores nómades (por medio de una pornología antropométrica), y divinizando su cultura como un producto espiritual muy antiguo del Dios cristiano (una teogonía etnológica). El monoteísmo primitivo, como el totemismo, se presentaba como el jeroglífico de un complejo cultural decadente, pero el giro monoteísta sustituía el "prejuicio egipcio" de la antropología totemista (prejuicio místico moderno del vestigio como jeroglífico) por el más antiguo "prejuicio teológico" (prejuicio antiguo del

104 F. Fanon, Peaux noires, masques blancs (Paris, 1952); P. Gilroy, The Black Atlantic. Modernity and Double Consciousness (Cambridge, 1993); Said, op.cit. 1989.

105 Manuel Manquilef, jLas tierras de Arauco! (Temuco, 1915). vestigio de la escritura como obra de Dios, que permite consolidar la clausura histórica y filosófica del interior europeo). ${ }^{106}$ Los etnógrafos como Gusinde eran llamados a rescatar e interpretar estos vestigios. Una vez registrados los textos dialógicos en las oficinas etnográficas, estos pasaban a alimentar la producción etnológica internacional. De esta manera, el texto de la cultura producido en el intercambio con informantes infantilizados, animalizados o proletarizados, era subsumido, al igual que el valor del trabajo (infantil) en la economía capitalista, en el proceso de acumulación de plus-valía que se capitalizaba en las grandes metrópolis coloniales de la disciplina antropológica.

\section{FUENTES DEL CONSULTA}

AGAMBEN, G., 2002 [1978]. Enfance et histoire. Destruction de l'expérience et origine de l'histoire. Payot, Paris.

AJENS, A. 2012. El tabernáculo quebrado. desclasificando a dios y/o al diablo. Anales de desclasificación 2(1). En prensa.

BAJTÍN, M. M. 1981. The Dialogic Imagination. Four Essays. Ed. Michael Holquist. University of Texas Press, Austin.

BASCOPÉ, J. 2011a. Antes de la ley. Salvajismo y comercio sexual en Tierra del Fuego y Patagonia austral, 18841920. En: Capitalismo y pornología. La producción de los cuerpos sexuados, J. Pavez y L. Kraushaar eds. pp. 180-216.Qillqa-Universidad Católica del Norte, Santiago. 2011b. Bajo tuición. Infancia y extinción en la historia de la colonización fueguina (Sentidos coloniales II). Corpus. Archivos virtuales de la alteridad americana 1 (1): $1-16$.

2012. La vida civil en El último confín de la Tierra. Sentidos coloniales IV. MS

BASTIDE, R. 1950. Sociologie et psychanalyse. Presses Universitaires de France, Paris.

BERMAN, J. 1996. The Culture as it Appears to the indian Himself: Boas, Hunt, and the Method of Ethnography. En: Volksgeist as Method and Ethic. Essays on Boa-

106 Para Durkheim y Mauss la decadencia del totemismo mostraba que los hechos etnográficos eran "restos de un sistema más completo de clasificación". Cf. E. Durkheim y M. Mauss, "De quelques formes primitives de classification", en M. Mauss, Oeuvres 2. Représentations collectives et diversité des civilisation (Paris, 1974 [1904]), p. 35. Sobre los prejuicios jeroglíficos en la escritura, ver J. Derrida, De la grammatologie (Paris, 1967) y A. Menard, 2009. "Escrituras indígenas. Notas para la genealogía de un inverosímil", M. Alvarado (ed.), II Simposio Internacional de Estéticas Americanas (Santiago, 2009), pp. 253-267. 
sian Ethnography and the German Anthropological Tradition. G. W. Stocking Jr. ed. pp. 215-256. The University of Wisconsin Press, Madison.

BOURGUIGNON. E. 1958. Review of Die Twiden, Pygmäen Und Pygmoide Im Tropischen Afrika, Martin Gusinde, 1956. American Anthropologist 60: 179-180.

BRIDGES, T., 2011. Los indios del último confín. Escritos para la South American Missionary Society 1869-1886. Zagier \& Urruty Publications. Ushuaia.

CÁRDENAS, R. 1997. Prólogo. En: Entre los fueguinos. W. Koppers. Ediciones de la Universidad de Magallanes, Punta Arenas.

CÁRDENAS R. y A. PRIETO, 1999. Entre los fueguinos: ¿una reacción antievolucionista de la escuela histórico-cultural? Anales del Instituto de la Patagonia 27: 89-98.

CARROL, D. 1983. The alterity of discourse: form, history, and the question of the political in M.M. Bakhtin. Diacritics (summer):65-83.

CLIFFORD, J. 1992 [1982] Person and Myth. Maurice Leenhardt in the Melanesian World. Duke University Press, Durham y Londres.

1995. Dilemas de la cultura. Antropología, literatura y arte en la perspectiva posmoderna. Paidós, Buenos Aires.

COOPER J., 1917. Analytical and Critical Bibliography of the Tribes of Tierra del Fuego and Adyacent Territory. Government Printing Office, Washington.

CORIAT, I. H. 1915. Psychoneuroses among primitive tribes. The Journal of Abnormal Psychology 10(3): 201-208. 1920. Repressed Emotions. Brentano's, New York.

DARTIGUES L. 2001/2002. La production conjointe de connaissances en sociologie historique : quelles approches? quelles sources? Le cas de la production orientaliste sur le Viêtnam 1860-1940. Genèses 43: 53-70.

DE CERTEAU M. 1975. L'écriture de l'histoire, Gallimard, Paris. DE MAN, P. 1990. Diálogo y dialogismo. En: La resistencia a la teoría. pp. 163-175. Visor, Madrid.

DERRIDA, J. 1967. La voix et le phénomène. Presses Universitaires de France, Paris.

1969. De la grammatologie. Minuit, Paris.

DIDI-HUBERMAN, G. 2002. L'image survivante. Histoire de l'art et temps des fantômes selon Aby Warburg. Minuit, Paris.

DULLEY I., 2010. Deus é feiticeiro. Práctica e disputa nas missoes católicas em Angola colonial. Annablume/ Fapesp, Sao Paulo.

DURKHEIM, E. y M. MAUSS, 1974 [1904]. De quelques formes primitives de classification, en M. Mauss, Oeuvres 2. Représentations collectives et diversité des civilisation. Gallimard, Paris.
FABIAN, J., 2006 [1983]. Le temps et les autres. Comment l'anthropologie construit son objet. Anacharsis, Paris.

FABIANI, J.-L., 2005. Faire école en sciences sociales: un point de vue sociologique. Cahiers du Centre de recherches historiques 36: 191-207.

2007. La généralisation dans les sciences historiques. Obstacle épistémologique ou ambition légitime? Annales. Histoire, Sciences Sociales 62(1):9-28.

FANON, F. 1952. Peaux noires, masques blancs. Seuil, Paris. FOUCAULT, M. 1966. Les mots et les choses. Gallimard, Paris. 1969. L'archéologie du savoir. Gallimard, Paris.

1976. Histoire de la sexualité I. La volonté de savoir. Gallimard/Le Seuil, Paris.

1999. Les anormaux. Cours au Collège de France. 1974-1975. Gallimard/Le Seuil, Paris.

2000. Defender la sociedad. Curso en el Collège de France. 1975-1976. Fondo de Cultura Económica, Buenos Aires.

FURLONG, Ch. W. 1916. The alaculoofs and the Yahgans, the World's Southermost Inhabitants. En: Proceedings Second Pan American Scientific Congress, Washington DC, pp. 224-234. 27 de diciembre 1915-8 de enero 1916.

GILROY, P. 1993. The Black Atlantic. Modernity and Double Consciousness. Harvard University Press, Cambridge.

GUEVARA, T. 1918. La Etnología araucana en el poema de Ercilla. Imprenta Barcelona, Santiago.

GUSINDE, M. 1922. Tercer viaje a la Tierra del Fuego. Publicaciones del Museo de Etnología y Antropología de Chile 2(3):417-436.

1924. Cuarta expedición a la Tierra del Fuego. Publicaciones del Museo de Etnología y Antropología 4(1/2):7-68.

1986 [1937]. Los indios de Tierra del Fuego. Tomo 2: Los Yamana. Centro Argentino de Etnología Americana, Buenos Aires.

1951. Hombres primitivos en la Tierra del Fuego: de investigador a compañero de tribu. Escuela de Estudios Hispano-Americanos, Sevilla.

1953. Anthropological Investigations of the Bushmen of South Africa. Anthropological Quarterly 26(1):20-28. 1955. Pygmies and Pigmoids: Twides of Tropical Africa. Anthropological Quaterly 28(1):3-61.

HORNBOSTEL, E. M. von, 1936. Fueguian Songs. American Anthropologist 38(3):357-367.

KELLER, C. 1947. Dios en Tierra del Fuego. Zigzag, Santiago. KOPPERS, W. 1924. Unter Feuerland-Indianern. Eine forschungsreise zu den südlichsten bewohnern der erde mit M. Gusinde. Verlegt von Strecker und Schröder, Stuttgart. 
1997. Entre los fueguinos. Ediciones de la Universidad de Magallanes, Punta Arenas.

LATOUR, B. 1989. La science en action. Introduction à la sociologie des sciences. La Découverte, Paris.

LEVY-BRULH, L. 1922. La mentalité primitive. Felix Alcan, Paris. 1927. Lâme primitive. Felix Alcan, Paris.

LIPSCHUTZ, A., 1972 [1968]. Los últimos fueguinos: transculturación y desculturación, extinción y exterminación. En: Perfil de Indoamérica de nuestro tiempo. pp. 199-228. Instituto Cubano del Libro, La Habana.

LIPSCHUTZ, A., G. MOSTNY y L. ROBIN, 1946. The bearing of ethnic and genetic conditions of the blood groups of three Fueguian Tribes. American Journal of Physical Anthropology 4(3):311-322.

LIPSCHUTZ, A., G. MOSTNY, H. HELFRITZ, F. JELDES y M. LIPSCHUTZ, 1947. Physical Characteristics of Fueguian. American Journal of Physical Anthropology 5(3):295-321.

LODGE, D. Después de Bakhtin. En: La lingüística de la escritura. Debates entre lengua y literatura, Nigel Fabb, Derek Attridge, Alan Durant y Colin MacCabe (comp.). pp. 97-109.Visor, Barcelona.

MANNHEIM, B. 1999. Hacia una Mitografía Andina. En Tradición oral andina y amazónica, Juan Carlos Godenzzi Alegre ed. pp. 47-79. CERABC/PROEIB ANDES, Cuzco.

MANQUILEF, M. 1914. ¡Las tierras de Arauco! Imprenta Modernista, Temuco.

MARY, A. 2010. La preuve de Dieu par les pygmées. Le laboratoire équatorial d'une ethnologie catholique, Cahiers d'études africaines 198/199/200:881-905.

MENARD, A. 2009. Escrituras indígenas. Notas para la genealogía de un inverosímil. En: II Simposio Internacional de Estéticas Americanas. M. Alvarado ed. pp. 253-267. Universidad Católica de Chile, Santiago.

2011. El exterminio como patrimonio. Ponencia en las Jornadas de Estudio Formas del colonialismo nacional. 14-15 de diciembre 2011, Punta Arenas, Museo Regional de Magallanes.

MENARD, A. y J. PAVEZ, 2007 (eds.). Mapuche y anglicanos. Vestigios fotográficos de la Misión Araucana de Kepe (1896-1907), OchoLibros \& LDC, Santiago.

MENARD, A. y J. PAVEZ, 2012. Pudor y raza en la pornología araucanista. Anales de desclasificación 2(1). En prensa.

MUDIMBE, V. Y., 1988. The invention of Africa. Gnosis, philosophy and the order of knowledge, Indiana U.P. \& James Carrey, Bloomington, Indiana y Londres.

PALMA, M. 2005. Un caso fotográfico a la luz de los viajes de Martin Gusinde a Tierra del Fuego (1918-1924). Revista Chilena de Antropología Visual 6:102-114.
PARENTINI, L. C., 1996. Introducción a la etnohistoria mapuche. DIBAM. Col. Sociedad y Cultura, Santiago.

PAVEZ OJEDA, J., 2003. Mapuche ñi nütram chilkatun/ escribir la historia mapuche. Revista de Historia Indígena 7:7-53. 2007. Africanismes à Cuba. Textes, images, classes (1812-1917). Tesis de doctorado. Ecole des Hautes Etudes en Sciences Sociales, Paris. MS.

2012. Fetiches kongo, momias atacameñas y soberanía colonial. Trayectoria de Gustavo Le Paige S.J. (1903-1980). Estudios Atacameños. Arqueología y antropología andinas 44. En prensa.

PEIRANO, M. 2004. 'In this context'. As várias histórias da antropologia. En: Antropologias, Histórias, Experiências, F. Arêas Peixoto, H. Pontes, L. Moritz Schwarcz orgs. pp. 99-121. Editora UFMG, Belo Horizonte.

SAID, E., 2003 [1978]. Orientalism, Penguin books, Londres. 1989. Representar al colonizado: los interlocutores de la antropología. En: Cultura y tercer mundo. 1. Cambios en el saber académico. Beatriz González Stephan ed. Nueva Sociedad, Caracas.

SCHMIDT, W. 1931. Origine et évolution de la religion. La Théorie et les Faits. Bernard Grasset, Paris.

STOCKING Jr., G. W., 1968. Race, Culture, and Evolution. Essays in the History of Anthropology. University of Chicago Press, Chicago y Londres.

1992. The Ethnographer's Magic. Fieldwork in British Anthropology from Tylor to Malinowski. En: The Ethnographer's Magic and Other Essays in the History of Anthropology. G. Stocking. pp.12-59. The University of Wisconsin Press, Madison.

2001. Books unwritten, turning points unmarked: notes for an anti-history of anthropology. En: Delimiting anthropology: occasional essays and reflections, G. Stocking. pp. 330-354. University of Wisconsin Press, Madison.

STOLER, A. L. 1995. Race and the education of desire. Foucault's History of sexuality and the colonial order of things. Duke University Press, Durham y Londres.

TONKO, J.C. 2000. Ajajema y Jeksolok. Informativo Indígena de Magallanes 1(3):1.

WILBERT, J. (ed.) 1976. Folk Literature of the Yamana Indians. Martin Gusinde's Collection of Yamana Narratives. University of California Press, Berkeley y Los Angeles.

WITTGENSTEIN, L. 1992. Observaciones a La Rama Dorada de Frazer. Tecnos, Madrid.

ZIMÓN, H. 1986. Wilhem Schmidt's Theory of Primitive Monotheism and Its Critique within the Vienna School of Ethnology. Anthropos 81(1/3):243-2 


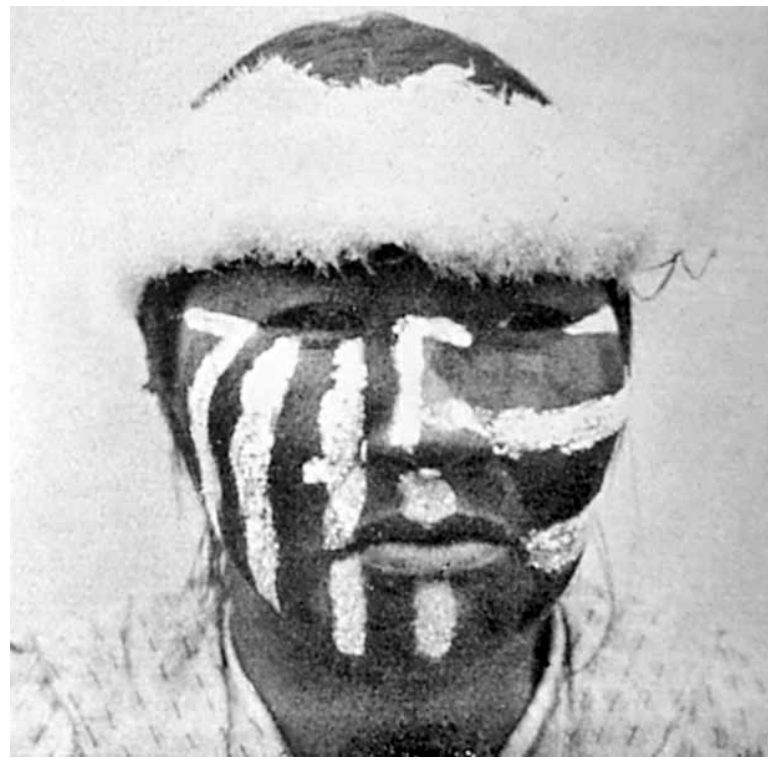

Fig. 1. Gertie, "informante" yámana, co-autora del talauwaia "por encargo" registrado M. Gusinde y W. Koppers. (Fuente: Koppers, 1924).

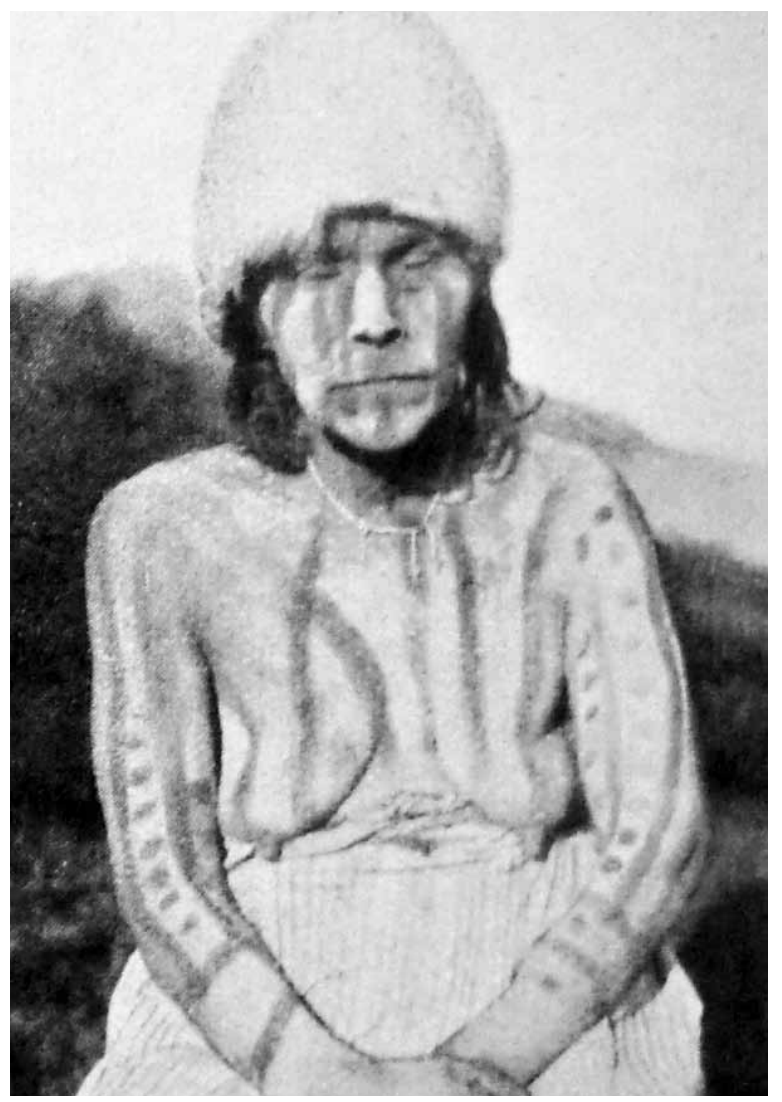

Fig. 2. Peine, "informante" yámana, co-autora del talauwaia "por encargo" registrado M. Gusinde y W. Koppers. (Fuente: Koppers, 1924). 


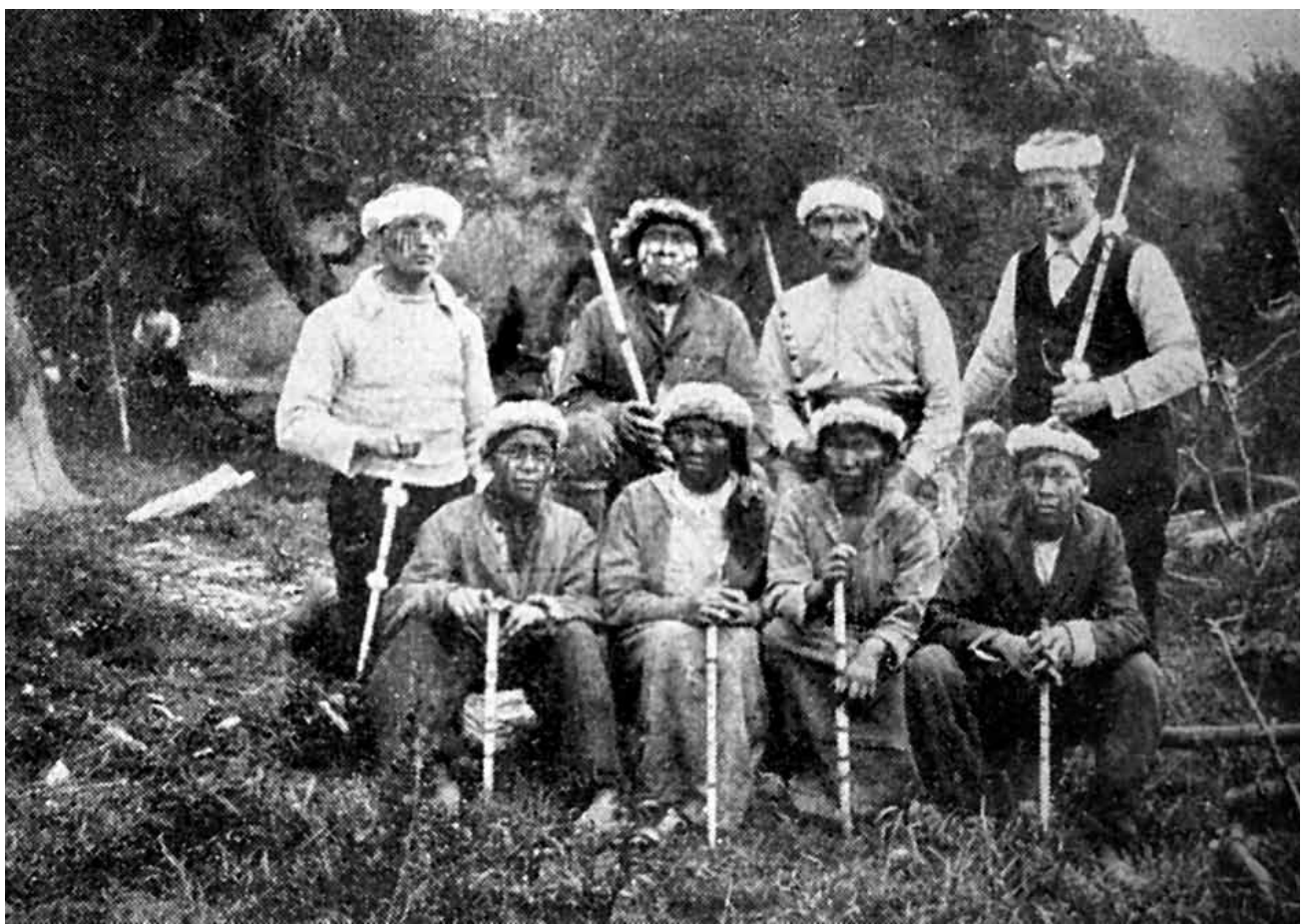

Fig. 3. Candidatos al chiehaus, arriba de derecha a izquierda: Gusinde, Masemikens, Santiago, Koppers; abajo de derecha a izquierda: Kinas, Elise, Julia, hijo de Walter. (Fuente: Koppers, 1924).

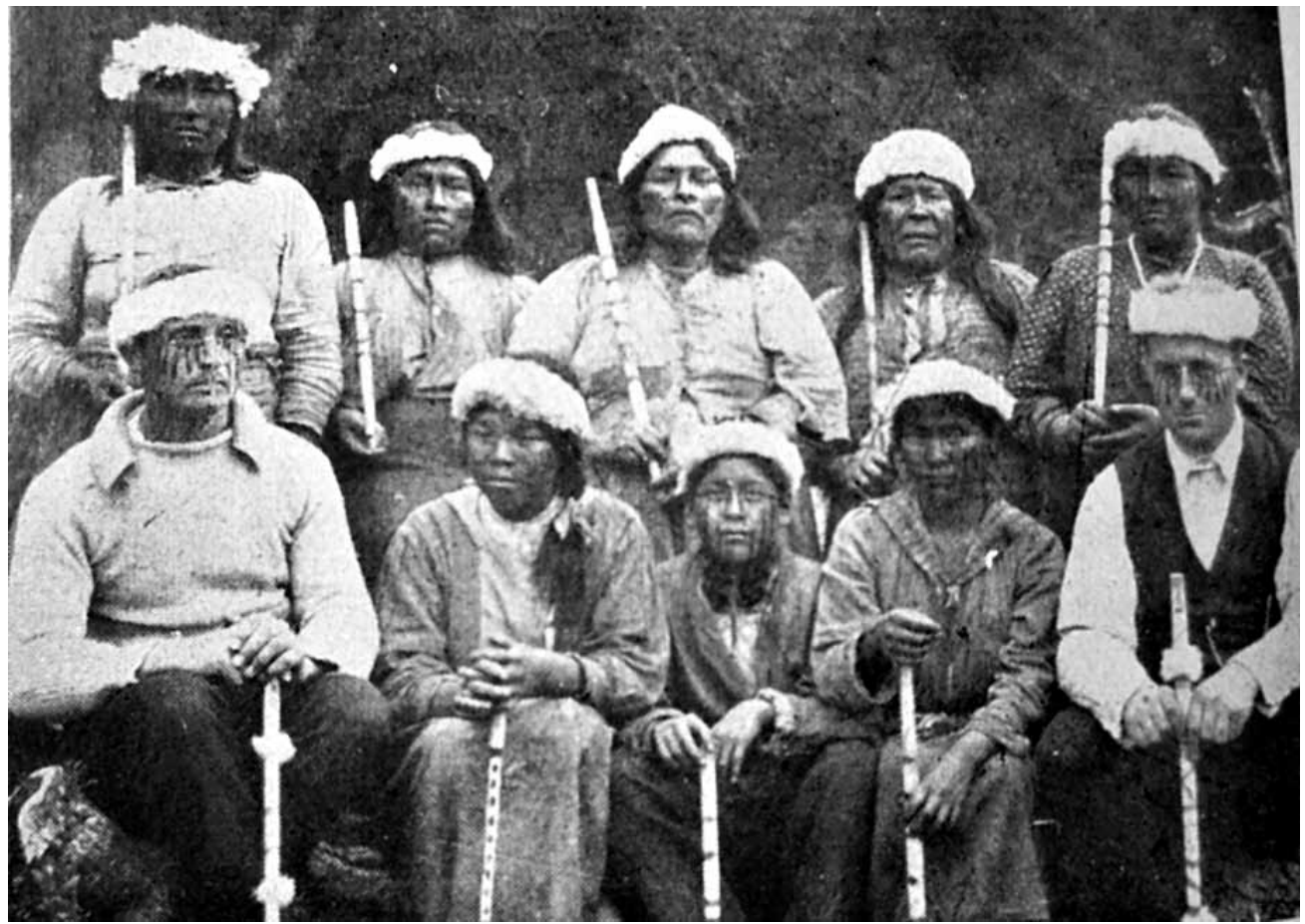

Fig. 4. De derecha a izquierda: Gertie, hija de Calderón, Emilia, hija de Charlin, Adelaida; abajo de derecha a izquierda: Gusinde, Elise, Kinas, Julia, Koppers. (Fuente: Koppers, 1924). 
